\title{
28 Research Square \\ Does bacterial weathering play a significant role in rock weathering?
}

\author{
Adil Binal ( $\nabla$ adil@hacettepe.edu.tr) \\ Hacettepe University Engineering Faculty https://orcid.org/0000-0002-4183-9430 \\ Aylin Sel \\ Hacettepe Universitesi Muhendislik Fakultesi
}

\section{Research Article}

Keywords: Bacterial weathering, Geomicrobiology, Bacillus subtilis, Bacillus pumilus, Porosity, Rock strength

Posted Date: February 19th, 2021

DOI: https://doi.org/10.21203/rs.3.rs-220205/v1

License: (c) (i) This work is licensed under a Creative Commons Attribution 4.0 International License. Read Full License 


\section{Abstract}

Bacterial weathering plays a significant role in rock weathering, yet only a limited number of studies was conducted on this topic. The recent rapid developments in geomicrobiology are expected to increase the pace of research in this area. The extent and duration of the biological weathering processes on mineral and rock samples and minerals preferred by bacteria are still not fully understood due to the wide variety of both bacterial species and rock types. Biological weathering of rock types found in Turkey has also not been studied before. Here, we investigated the effects of two species of bacteria actively contributing to rock weathering on three rock types commonly used as building stone materials in Turkey. Granite, andesite, and limestone samples could interact with Bacillus species (B. subtilis and B. pumilus) in closed system reactors. Samples obtained from these reactors were analysed via Scanning Electron Microscopy (SEM) monitoring to identify morphological features and chemical composition changes. Chemical elements consumed most by bacteria were identified. Changes in the colour index were determined via RGB measurements. The effects of experimental conditions on bacterial growth were monitored via daily optical density measurements. The effects of bacteria on the physical properties of rock samples were also evaluated. B. subtilis and B. pumilus were found to be more aggressive on limestone/andesite and granite, respectively.

\section{Introduction}

Rock decay is simply described as the adaptation of rocks to varying physicochemical conditions on the ground surface (Ehrlich 2002). Mineralogical components of rocks are altered and modified upon exposure to earth surface conditions in response to different atmospheric agents and insolation that may result in disaggregation (physical weathering) or decomposition (chemical weathering) of the rock. Biological weathering occurs when these processes are assisted by biological processes (de Oliveira Frascá 2018). In biological weathering, plant roots cause physical deformations in rocks by applying pressure to form cracks. Likewise, rock surfaces and pores are continuously subjected to degradation by fungi and lichens (Costerton et al. 1994). Biological impact, especially that of microorganisms, is the most critical factor controlling the amount and speed of rock decay (Gorbushina and Krumbein 2005). Various species of microorganisms are known to be active in various geological processes (Todar 2020). The primary effect of microorganisms is the acceleration of physical and chemical decay of the rock, often accompanied by the formation of secondary minerals such as poorly-ordered aluminosilicates and clays (Cockell 2011). Microbial/bacterial weathering of minerals is a critical process promoting ecological restoration. However, nutrient release and mineral weathering abilities of bacteria vary between species (Wu et al., 2017).

Organisms found on rock surfaces form biofilms in humid environments. Biofilm is a layer of microorganisms embedded within a polysaccharide matrix and may include mixed-species populations. Microorganisms in these populations obtain elements and minerals necessary for their survival and growth by disintegrating rocks (Costerton et al. 1994, Adamo and Violante 2000). B. subtilis and B. megaterium were found to be the most effective among 21 bacterial species investigated for their hematite degradation performance (Gonzalez et al. 1999). The dissolution of gypsum mineral was also found to be 30 times higher in the presence of bacteria (Sun and Friedmann 1999). The iron dissolution rate of the hornblende 
mineral was found to be increased approximately 20 times in the presence of bacteria in the environment (Kalinowski et al. 2000). B. cereus and B. pumilus cells were shown to dissolve iron, silica and aluminium elements in quartz, reduce the free iron oxide species, and dissolve the potassium from the mica mineral (Styriakov et al. 2003). Degradation of the pyrite mineral was observed to increase in a bacteria-containing solution (Fowler et al. 2001). B. subtilis bacteria appear to have a strong influence on granite weathering by forming pits and appear to preferentially select an optimum place to adhere to the mineral and collect essential elements from the mineral (Song et al. 2007). Bacterial surfaces also play an essential role in calcium precipitation and biomineralisation processes inside the rock. Because of the presence of several negatively charged groups, at a neutral $\mathrm{pH}$, positively charged metal ions can be bound on bacterial surfaces, favouring heterogeneous nucleation (Daryono et al. 2019). Finally, the amount of calcium was found to increase because of the bacterial activity in SEM and EDS analyses performed on historical churches' frescos (Milanesi 2006).

Our current knowledge regarding which bacteria species prefer which rock type to colonise and reproduce is highly limited. Previous studies (Lee et al. 2000, Kalinowski et al. 2000) mostly focused on reducing the grain size of a single mineral. Furthermore, no studies included more than one mineral, and no study was conducted directly on the rock without dusting the sample. Rock material used within buildings or structures of historical and cultural significance is not preserved effectively because of bacterial activity. Bacterial weathering of historical buildings has also not yet been thoroughly investigated. Here, we studied the weathering effects of Bacillus subtilis and Bacillus pumilus on granite, andesite, and limestone, which are used commonly used as exterior cladding materials in buildings in Turkey.

\section{Materials And Methods}

Granite, limestone, andesite rocks which are used as exterior cladding materials in Turkey were obtained from Gölbaşı and Pergamum quarries. Bacillus subtilis 168 (ATCC 23857) (Fajardo-Cavazos and Nicholson 2006) and Bacillus pumilus (ATCC 7061-3) (Benardini et al. 2003) were used in the experiments.

\section{Rock Samples}

Granite samples were found to include quartz, greenish amphibole, subhedral pyroxene, plagioclase, chlorite and biotite (Fig. 1) in microscopic analyses.

Gölbaşı andesite was found to include hypo-crystalline, and over $90 \%$ plagioclase porphyritic (Fig. 2). Alkali feldspars were present in the form of microlites in the matrix, and amphibole was also observed. Biotite was observed as dark-coloured and opaque minerals.

The rock is fine-grained. As a result of the modal analysis, it was determined that the rock has $~ 96 \%$ carbonate and $\sim 4 \%$ quartz crystals (Fig. 3), as well as $\sim 98 \%$ of the carbonate minerals, are calcite and $\sim$ $2 \%$ dolomite. Calcite is characterised by anhedral crystals, while dolomite is characterised by hemisphericaleuhedral (rhombohedral shaped) crystals. The rock has been described as crystallised limestone.

\section{Determination of Bacterial Strains for Testing}


The bacterial species commonly found on rocks in nature were identified via literature search (Bernardini et al. 2003, Stassi et al. 1998, Turtura et al. 2000). Bacterial to be included in this study was then selected based on the results of this literature research. Here, we reasoned that using bacterial species that were previously isolated and used in other relevant research projects would yield more reliable results. Bacillus subtilis 168 (ATCC 23857) (Fajardo-Cavazos and Nicholson, 2006) and Bacillus pumilus (ATCC 7061-3) (Bernardini et al. 2003) were obtained from American Type Culture Collection (ATCC).

Prokaryotes and eukaryotes characterised as geological microbial agents include various species.

Prokaryotes are unicellular organisms (e.g. bacteria) without a true nucleus or membrane-bound organelles, and the prokaryotic genome is a single circular DNA. In contrast, a eukaryote is a unicellular or multicellular organism consisting of (a) cell(s) with membrane-bound intracellular organelles and nuclei including chromosomes (e.g. plants, animals, fungi, and protozoans). Geomicrobially active prokaryotes are members of Archaeobacteria and Eubacteria. Bacillus is a genus of aerobic, rod-shaped, gram-positive, and endospore-forming bacteria. Bacillus species may be pathogenic or non-pathogenic and are abundantly found in natural environments, including soil and air. They also play an active role in food degradation. Endospores formed by Bacillus species allow survival of bacterial cells under unfavourable conditions such as extremely high or low temperatures. This is accomplished by minimising the cell surface and reducing the metabolic activity to non-detectable levels (Ehrlich 2002).

\section{Characteristics of Bacillus subtilis}

B. subtilis is a gram-positive and aerobic species of bacteria capable of forming heat-resistant endospores. $B$. subtilis is also the most extensively studied species of the Bacillus genus, and the $B$. subtilis genome is the best-characterised genome in this group. The bacterium has a length of about 1.5-3 $\mu \mathrm{m}$, a width of 0.5$0.8 \mu \mathrm{m}$, and a rod-shaped structure. $B$. subtilis is considered a thermo-tolerant bacterium and usually found at temperatures lower than those favoured by thermophilic bacteria. $B$. subtilis cells can survive at $20-50^{\circ} \mathrm{C}$ in soil, air and hot spring waters. Further information on the $B$. subtilis strain used here is given in Table 1.

Table 1

Summary information on the tested Bacillus subtilis strain 168 (ATCC 23857)

\begin{tabular}{|ll|}
\hline Organism name & Bacillus subtilis (Ehrenberg) Cohn \\
\hline No & 168 \\
\hline Supplier & RC Clowes \\
\hline Biological threat level & 1 \\
\hline Growth media & ATCC medium 425 \\
\hline Optimum growth temperature & $26^{\circ} \mathrm{C}$ \\
\hline
\end{tabular}

\section{Characteristics of Bacillus pumilus}


B. pumilus is more abundant in soil than B. subtilis. B. pumilus is a rod-shaped, gram-positive, and aerobic bacterial species. Although their biohazard level is one, some B. pumilus strains may cause food poisoning. They can survive in soil, air, and water, and grow optimally at an average temperature of $30^{\circ} \mathrm{C}$ (Öner 1987). Further information on the B. pumilus strain used here is given in Table 2.

Table 2

Summary information on tested Bacillus pumilus strain

\begin{tabular}{|ll|}
\hline Organism & Bacillus pumilus (Meyer and Gottheil) \\
\hline No & 503 [IFO 12600] \\
\hline Supplier & ATCC $\circledast 7061^{\mathrm{m}}$. \\
\hline Biological threat level & 1 \\
\hline Growth media & ATCC medium 3 \\
\hline Optimum growth temperature & $30^{\circ} \mathrm{C}$ \\
\hline
\end{tabular}

\section{Producing Bacteria}

\section{Growth Medium}

\section{B. subtilis Growth Medium}

Unless stated otherwise, $B$. subtilis cells were grown in the medium recommended by the ATCC for Bacillus subtilis (ATCC Medium \#415: Potato Extract medium (Fig. 4) (Table 3).

Table 3

B. subtilis growth medium (ATCC Medium \#415)

\begin{tabular}{|ll|}
\hline Nutrient Broth (Merck) & $\mathbf{2 3 . 0 ~ g}$ \\
\hline Potato extract & $20 \mathrm{ml}$ \\
\hline Distilled water & $1000 \mathrm{ml}$ \\
\hline
\end{tabular}

Sliced potatoes $(300 \mathrm{~g}$ ) were boiled in $500 \mathrm{ml}$ distilled water for half an hour to obtain $20 \mathrm{ml}$ of potato extract. The resulting foam on top was removed. The extract was sterilised via autoclaving at $121^{0} \mathrm{C}$ for 15 minutes, and the final growth medium was prepared by adding other components of the medium according to the final total volume. The resulting liquid medium $(500 \mathrm{ml})$ was autoclaved for 15 minutes at $121^{\circ} \mathrm{C}$ for a second time.

\section{B. pumilus Growth Medium}


Bacillus pumilus cells were grown in the ATCC \#3 Nutrient Medium (Table 4), recommended by ATCC for this microorganism. The required components were added to the solution until the final total volume was reached, and the solution was then heated until a homogeneous mixture was obtained. Then, the reactor, including $500 \mathrm{ml}$ medium, was autoclaved for 15 minutes at $121^{\circ} \mathrm{C}$.

Table 4

B. pumilus growth medium

\begin{tabular}{|ll|}
\hline Nutrient Broth (Merck) & $\mathbf{2 3 . 0 ~ g ~}$ \\
\hline Distilled water & $1000 \mathrm{ml}$ \\
\hline
\end{tabular}

\section{Growth of Bacteria}

Bacteria were obtained from the ATCC in a freeze-dried state (Fig. 5). Bacteria were first transferred to solid and liquid media, which were prepared according to the recommendations by the ATCC.

\section{Bacillus subtilis Growth}

Bacillus subtilis cells were supplied in glass ampoules. First, the ampoule containing the bacteria was sterilised by washing with alcohol in a sterile air cabinet. A total of $0.5 \mathrm{ml}$ of the previously prepared ATCC medium \#415 was then injected into this ampoule. After thoroughly mixing, the mixture in this ampoule was added to the growth medium. Bacteria were incubated in this medium at $26^{\circ} \mathrm{C}$ for 24 hours. Colonies formed at the end of 24 hours were divided into $5 \mathrm{ml}$ of solid and liquid growth media (Fig. 6).

\section{Bacillus pumilus Growth}

Bacillus pumilus cells were supplied in glass ampoules. The ampoule was first sterilised by washing with alcohol in a sterile air cabinet. Then, the bulb head was thoroughly heated, and a few drops of distilled water were dropped on it to break the glass. The cotton tip inside the ampule was removed. A total of $1 \mathrm{ml}$ of previously prepared ATCC \#3 Medium was then injected into the ampoule. After thoroughly mixing, $5 \mathrm{ml}$ of this mixture was added to the growth medium. The bacteria were incubated for 36 hours at $30^{\circ} \mathrm{C}$ in this medium. Colonies formed at the end of 36 hours were transferred to $5 \mathrm{ml}$ solid and liquid media (Fig. 7).

\subsection{Sterilisation}

Sterilisation of laboratory equipment and media was performed to kill vegetative forms as well as spores of microorganisms (Temiz 1996). All materials used in the experimental setup were first treated with heat. First, the dry-heat sterilisation was performed. Then, all media and reactors were subjected to pressurised steam treatment (i.e. autoclaving). Here, sterilisation was performed at 120 bar and $121^{\circ} \mathrm{C}$ for 15 minutes (Fig. 8).

Sterilised materials were placed into a sterile hood (Fig. 9). Cultivation of bacteria was carried out in the reactor connected to an air pump.

\subsection{Experimental Setup}


Each reactor was a $1 \mathrm{~L}$ autoclavable glass bottle with three glass pipettes attached to them. Two of these glass pipettes were used for air circulation, and one was used for sampling. A certain portion of the sampling pipette $(5 \mathrm{~cm})$ was bent down at an angle of $45^{\circ} \mathrm{C}$ to prevent contamination of the reactor from the outside during sampling (Fig. 10). This portion of the sampling pipette was sterilised by burning before and after each sampling. Micro-filters ( 0.2 micron) were mounted to the tip of glass pipettes that provided air circulation to prevent contamination. Autoclavable silicone hose was used for connecting the components of the reactor. The air motor used was a KNF Neuberger N 022 AN.18 Model vacuum pump with 4 bar capacity. The air supplied by this motor was distributed equally to each of the 14 reactors. The air motor was cooled down daily using ice blocks to prevent overheating. Each reactor was wrapped with aluminium foil to protect against sunlight or other light sources.

The following steps were performed for the preparation of the experimental setup (Fig. 10):

1. First, the sterilisation of materials used in the experimental setup was performed,

2. Nutrients for bacterial growth and rock samples were prepare,

3. Rock samples were placed into the reactors, and reactors were autoclaved,

4. Bacteria were inoculated into the reactors,

5. Reactors were connected to the air motor to start cultivation.

The experimental setup consisted of 14 reactors and an air motor. Seven reactors were prepared to observe the interaction between water, rock sample, and bacterial population, whereas the remaining seven reactors were prepared to study the interaction between the rock sample and bacteria in a growth medium with nutritional supplements (Tables 5 and 6 ). All experiments were carried out at room temperature $\left(23^{\circ} \mathrm{C}\right)$.

Table 5

Reactor conditions for $B$. subtilis experiments

\begin{tabular}{|c|c|c|c|c|c|c|c|}
\hline Reactor No & 1 & 2 & 3 & 4 & 5 & 6 & 7 \\
\hline Bacterial Species & \multicolumn{7}{|c|}{ B. subtilis } \\
\hline Growth Media & + & - & + & - & + & - & + \\
\hline Rock Type & Granite & Granite & Andesite & Andesite & Limestone & Limestone & - \\
\hline \multirow{3}{*}{$\begin{array}{l}\text { Core No } \\
\text { in Reactor }\end{array}$} & G1 & G4 & A1 & A5 & K1 & K4 & - \\
\hline & G2 & G5 & A2 & A7 & K2 & K5 & \\
\hline & G3 & G6 & A4 & A8 & K3 & K6 & \\
\hline $\begin{array}{l}\text { The cube-shaped sample } \\
\text { in the reactor for SEM }\end{array}$ & G1 & G2 & $\mathrm{A} 1$ & A2 & K1 & $\mathrm{K} 2$ & - \\
\hline
\end{tabular}


Table 6

Reactor conditions for $B$. pumilus experiments

\begin{tabular}{|c|c|c|c|c|c|c|c|}
\hline Reactor No & 8 & 9 & 10 & 11 & 12 & 13 & 14 \\
\hline Bacterial Species & \multicolumn{7}{|c|}{ B. pumilus } \\
\hline Growth Media & + & - & + & - & + & - & + \\
\hline Rock Type & Granite & Granite & Andesite & Andesite & Limestone & Limestone & - \\
\hline \multirow{3}{*}{$\begin{array}{l}\text { Core No } \\
\text { in Reactor }\end{array}$} & G8 & G7 & A9 & A12 & K7 & K11 & - \\
\hline & G9 & G11 & A10 & A13 & K9 & K12 & \\
\hline & G10 & G12 & A11 & A14 & K10 & K13 & \\
\hline $\begin{array}{l}\text { The cube-shaped } \\
\text { sample in the reactor } \\
\text { for SEM }\end{array}$ & G3 & G4 & A3 & A4 & K3 & K4 & - \\
\hline
\end{tabular}

The reactors were left to run for eight weeks. Optical densities of samples taken from the reactors were measured at certain time intervals using a spectrophotometer. The spectrophotometer is a kind of photometer frequently used to find the concentration of the substance in the solution. The working mechanism of the spectrophotometer is based on the principle of transmitting light in specific spectrums through the prepared solution and finding out how much of this beam is absorbed by the solution. The higher the concentration of a substance in a solution, the more absorbance of light is observed. Different sample types absorb light at different wavelengths. Here, the light at $600 \mathrm{~nm}$ wavelength was used to measure the concentration of bacteria in samples. The sample was placed in a special container called a cuvette, which is located between the light source and the light detector. The wavelength values obtained are converted into absorbance values using the Beer-Lambert Law. A reference solution, which does not contain the substance to be examined, is also necessary to make accurate measurements. Pure water was used as a reference solution here.

Bacterial concentration in the reactors was measured using the spectrophotometer. Higher absorbance values were obtained from samples with higher concentrations of bacteria. This way, quantitative information on the bacterial growth rate was obtained as well. At the end of each experiment, samples taken from the reactors containing nutrients and bacteria were also subjected to water chemistry analyses. The results obtained from these analyses were compared to those from the solution containing only the growth medium. Sodium, phosphorus, potassium, calcium, magnesium, silicon, zinc, manganese, iron, nickel, copper, and chromium analyses were performed for B. subtilis experiment samples. For B. pumilus experiment samples, aluminium, sodium, phosphorus, potassium, calcium, magnesium, silicon, zinc, manganese, iron, nickel, copper, and chromium analyses were performed. 
Porosity and uniaxial compressive strength parameters are widely used to assess the weathering degree of various rock types (Gupta and Rao, 2001; Sousa et al., 2005; Binal, 2009; Binal, 2019; Li, 2020). The effects of weathering on rocks may be reflected on changes in index properties such as dry density, void ratio, clay content, and P-wave velocity. Due to these properties' geotechnical significance, they are used by geotechnical engineers to assess the degradation degree of rocks and to quantitatively classify weathered rocks (Heidari et al., 2013).

\section{Determination of the Apparent Porosity and Water Absorption by Weight}

This experiment was carried out to determine the apparent porosity of rock samples with regular geometry. The apparent porosity and void ratio of the rock samples used in the study were determined by considering the experimental method proposed by ISRM (2015). Five pieces of $25 \mathrm{~mm}$ diameter core were prepared for each reactor. Samples were dried in the oven with a temperature set at $105^{\circ} \mathrm{C}$ for 24 hours. Then, their dry weights were determined. Five samples for each reactor core of $25 \mathrm{~mm}$ diameter were prepared. Before tests, samples were dried in the oven with a temperature set at $105^{\circ} \mathrm{C}$ for 24 hours. After dry weight measurements, samples were kept in a beaker filled with water for 48 hours, and their surface was dried with a dry paper towel and then weighed on a sensitive scale. Finally, the dry surface wet weights were determined. The change in apparent porosity $(n)$ and water absorption by weight $\left(A_{w}\right)$ values were determined at the beginning and the end of the experiment.

\section{P-wave Tests}

This experiment was carried out to determine the propagation velocity of the compression (P), and shear (S) waves passed through the rock samples. The methods proposed by ASTM D2845-08 were used as basis. The lower and upper surfaces of the core samples were covered with conductive gel to increase the contact between the sender and receiver. After that, the transition time $\left(T_{p}\right)$ of the shear wave was measured.

\section{Uniaxial Compressive Strength Tests}

This experiment was carried out to determine the uniaxial compressive strength of rock material samples with a cylindrical shape. The experiments were based on the method proposed by ISRM (2015). During the test, a hydraulic press was used to load the sample at a constant speed continuously and axially. Samples were loaded for a duration of 5-10 minutes. Values were calculated using Eq. 1.

$\sigma_{\mathrm{C}}=\mathrm{F} / \mathrm{A}(1)$

Here, F denotes force at the failure, and A denotes the circular cross-section area of the core sample.

ISRM standards suggest compression strength for NX core. In this study, small diameter cores were preferred due to the requirement of optimal use of the experimental setup. Although not widely used in practice, a $25 \mathrm{~mm}$ diameter core was still used due to compatibility with the reactors. Standard $50 \mathrm{~mm}$ diameter equivalent uniaxial compressive strength values were calculated from the following equation proposed by Hoek and Brown (1980) (Eq. 2).

$\sigma_{\mathrm{C}}=\sigma_{\mathrm{Cd}} /(50 / \mathrm{D})^{0.18}(2)$ 
Here, $\sigma_{\mathrm{c}}$ is equivalent to $50 \mathrm{~mm}$ diameter core uniaxial compressive strength, $\sigma_{\mathrm{cd}}$ is the uniaxial compressive strength of "D" diameter sample, and D is the diameter of the sample $(\mathrm{mm})$

\section{Colour Changes}

At the beginning and the end of the experiment, RGB (red, green, blue) values were read with a special device (Lutron RGB-1002) from the surfaces of rock samples according to ASTM D 2244 colour tolerance and difference determination standards. Values were converted to $X, Y$ and $Z$ values using the equations given below (Eq. 3-5).

$$
\begin{aligned}
& X=0.4124\left(\frac{R+0.055}{1.055}\right)^{2.4}+0.3576\left(\frac{G+0.055}{1.055}\right)^{2.4}+0.1805\left(\frac{B+0.055}{1.055}\right)^{2.4} \\
& Y=0.2126\left(\frac{R+0.055}{1.055}\right)^{2.4}+0.7152\left(\frac{G+0.055}{1.055}\right)^{2.4}+0.0722\left(\frac{B+0.055}{1.055}\right)^{2.4} \\
& Z=0.0193\left(\frac{R+0.055}{1.055}\right)^{2.4}+0.1192\left(\frac{G+0.055}{1.055}\right)^{2.4}+0.9505\left(\frac{B+0.055}{1.055}\right)^{2.4}
\end{aligned}
$$

$X, Y$ and $Z$ values are the fluorescence values $\left(X_{n}: 103.28, Y_{n}: 100\right.$, and $\left.Z_{n}: 69.026\right)$ based on ASTM D2244 standard. The equations given below were used to obtain (Eq. 6-7) L, a and b values .

$$
\begin{aligned}
& \mathrm{L}=116\left(\frac{\mathrm{Y}}{\mathrm{Y}_{\mathrm{n}}}\right)^{1 / 3}-16 \\
& \mathrm{a}=500\left[\left(\frac{\mathrm{X}}{\mathrm{X}_{\mathrm{n}}}\right)^{1 / 3}-\left(\frac{\mathrm{Y}}{\mathrm{Y}_{\mathrm{n}}}\right)^{1 / 3}\right] \\
& \mathrm{b}=200\left[\left(\frac{\mathrm{Y}}{\mathrm{Y}_{\mathrm{n}}}\right)^{1 / 3}-\left(\frac{\mathrm{Z}}{\mathrm{Z}_{\mathrm{n}}}\right)^{1 / 3}\right]
\end{aligned}
$$

The following equation (Eq. 9) was then used to calculate colour change level using the values of $L, a$, and $b$ obtained as above.

$$
\mathrm{E}_{\mathrm{Lab}}=\sqrt{(\Delta \mathrm{L})^{2}+(\Delta \mathrm{a})^{2}+(\Delta \mathrm{a})^{2}}
$$

\section{Scanning Electron Microscopy (SEM) and imaging}

SEM imaging the solid sample surface was performed with a high energy electron beam. Remaining signals were converted into electrical signals using different detectors. Secondary electron image detector (SE) was used to determine the topography of the surface. Image of backscattered electrons (BSE) was used to determine both the chemical composition and topography. However, low-resolution images were obtained. EDS detector was used for chemistry analyses. SEM was used in this study to observe changes in the dimensions of micro voids on predetermined minerals and to determine possible chemical changes. Proper sample preparation is essential for a high-quality SEM image. The sample should be able to withstand the 
strong vacuum applied in SEM, and there should be no bubble-shaped gas release. Moreover, since the image is obtained electronically, the conductivity of the sample is also an important consideration. Samples used in SEM must be dry, free from dust, oil and dirt.

Six pieces of andesite, granite, and limestone samples each were cut into $10 \times 10 \times 5 \mathrm{~mm}$ cubes. Five samples of each rock type were used for measurements, with one sample being left as reserved. The samples were polished with $0.25 \mu \mathrm{m}$ diamond powder. T-shaped lines were drawn on these polished samples to determine reference points (Fig. 11). The imaging was done with reference to these lines. The samples were de-ionised with water after cleaning with acetone in the ultrasonic vibrator. Samples were dried at $105^{\circ} \mathrm{C}$ and then fixed onto the plate with carbon to ensure conductivity. One example in each reactor did not contact bacteria and used as control.

Preparation of samples for the imaging of bacterial colonies using involves a different procedure. Since SEM is a vacuum-operated microscope, the water content of bacteria must be removed. For this purpose, colonies taken from the agar plates were applied onto carbon tapes. The water content was then removed by leaving these in solutions containing $20 \%, 40 \%, 60 \%, 80 \%$, or $100 \%$ alcohol. The sample was kept in the oven for 1-2 minutes and then coated and visualised under SEM (Fig. 12).

Different SEM imaging methods were tried on samples containing bacteria. Eventually, the carbon content of bacteria was determined to cause problems in the imaging of samples also covered with carbon. With gold coating, the expansion of the micropores was found to be problematic since the diamond powder was used to clean the coating. In addition, the materials used in the coating were found to be placed in scratches, and heavy chemicals were needed to remove them. However, limestone, one of the rock types used in this study, is not resistant to these chemicals, and therefore cleaning of coating has created problems. Due to the problems encountered above, the coating was not used in SEM imaging. Instead, uncoated samples were imaged under low vacuum conditions. Samples were first subjected to SEM imaging before starting each experiment. At the end of the experiments, the sample was imaged before and after cleaning of the bacterial colonies. Before the experiment, each sample was left in ultrasonic vibrator for 15 minutes and then washed with acetone and distilled water. Then, the sample was dried in the oven with the temperature set at $105^{\circ} \mathrm{C}$ for 2 hours. The imaging was done concerning the $T$ line. Since bacteria prefer to grow especially in fractures and cavities, images were taken from fractures and cavities on the surface of samples. Sections taken in the first imaging were framed, and images were taken from the same frames in subsequent views (Fig. 13). Images were taken at 500, 1000 and 2000 magnifications.

EDS detector was used for chemical analysis of minerals. SEM settings used are given in Table 7. 
Table 7

SEM operating conditions.

\begin{tabular}{|ll|}
\hline Z (height) & $11 \mathrm{~mm}$ \\
\hline Vacuum & $60 \mathrm{~Pa}$ \\
\hline EHT & $30 \mathrm{kV}$ \\
\hline Filling I & $2.611 \mathrm{~A}$ \\
\hline Beam Current & $100 \mathrm{kV}$ \\
\hline I Prop & $40 \mathrm{pA}$ \\
\hline Focus & $8.5 \mathrm{~mm}$ \\
\hline
\end{tabular}

\section{Results And Discussion}

In the following, changes in the physical properties and strength metrics of rock samples before and after contact with bacteria, surface colour changes, changes in the chemistry and optical density values, and SEM imaging results are presented and discussed.

\section{Physical Properties and Strength Test Results}

\section{Apparent Porosity, Water Absorption by Weight, and Void Ratio}

Before starting experiments and conducting tests for each sample, diameter and length measurements were performed. Some differences were also detected in the reactor porosity, and the void ratio was measured. Apparent porosity and void ratio changes of rock samples contacting $B$. subtilis and $B$. pumilus were higher with the NB- condition (i.e. no growth media) (Fig. 14-15). The existence of growth medium (i.e. NB+) decreased the apparent porosity (Table 8). The decrease in the apparent porosity was observed to occur as a result of the placement of the nutrients within the pores and biofilm formation. In NB-conditions, there was an increase in apparent porosity of granite and andesite. Although the existence of growth medium accelerated the increasing number of bacterial cells, the porosity values still decreased due to the obstruction of the pores. On limestone, an increase in apparent porosity was observed in NB- conditions. Although this change was negligible in samples treated with $B$. pumilus, it is very high in samples treated with $B$. subtilis. The observation of organic residues on this sample under SEM explains this result. 
Table 8

Changes in apparent porosity and void ratio values

\begin{tabular}{|c|c|c|c|c|c|c|c|c|c|}
\hline $\begin{array}{l}\text { Bacillus } \\
\text { species }\end{array}$ & Rock Type & $\begin{array}{l}\text { Reactor } \\
\text { No }\end{array}$ & NB & $\begin{array}{l}\text { Before test } \\
\text { n (\%) }\end{array}$ & $\sigma$ & $\begin{array}{l}\text { After test } \\
\mathrm{n}(\%)\end{array}$ & $\sigma$ & $\begin{array}{l}\Delta \mathrm{n} \\
(\%)\end{array}$ & $\mathbf{N}$ \\
\hline \multirow[t]{6}{*}{ B. subtilis } & \multirow[t]{2}{*}{ Granite } & 1 & + & 1.36 & 0.03 & 1.40 & 0.44 & -3.84 & 5 \\
\hline & & 2 & - & 1.06 & 0.19 & 1.17 & 0.15 & -11.39 & \\
\hline & \multirow[t]{2}{*}{ Andesite } & 3 & + & 10.84 & 0.28 & 9.78 & 0.60 & 9,77 & 5 \\
\hline & & 4 & - & 10.49 & 0.23 & 10.86 & 0.33 & $-3,56$ & \\
\hline & \multirow[t]{2}{*}{ Limestone } & 5 & + & 7.98 & 0.40 & 7.00 & 0.51 & 12.39 & 5 \\
\hline & & 6 & - & 8.37 & 0.23 & 7.80 & 0.22 & 6.84 & \\
\hline \multirow[t]{6}{*}{ B. pumilus } & \multirow[t]{2}{*}{ Granite } & 8 & + & 1.05 & 0.44 & 0.92 & 0.31 & 8.65 & 5 \\
\hline & & 9 & - & 1.04 & 0.24 & 1.30 & 0.15 & -28.33 & \\
\hline & \multirow[t]{2}{*}{ Andesite } & 10 & + & 11.00 & 0.30 & 9.94 & 0.45 & 9.56 & 5 \\
\hline & & 11 & - & 15.27 & 7.22 & 15.38 & 7.27 & -0.76 & \\
\hline & \multirow[t]{2}{*}{ Limestone } & 12 & + & 8.46 & 0.17 & 7.87 & 0.29 & 7.03 & 5 \\
\hline & & 13 & - & 8.24 & 0.33 & 8.19 & 0.46 & 0.67 & \\
\hline
\end{tabular}

An analysis of the differences in water absorption amount by weight for each reactor yielded the following results (Table 9). In rocks contacting $B$. subtilis and $B$. pumilus, water absorption change by weight was higher in NB-conditions (Fig. 16 and Fig. 17). The effects of B. pumilus and B. subtilis here was higher on granite and limestone, respectively. Similar results were obtained for apparent porosity with water absorption by weight. In NB + conditions, the decrease in apparent porosity is considered to cause a decrease in water absorption by weight. For limestone, an increase in porosity was observed in NBconditions. Although this change is negligible with B. pumilus, it is high with $B$. subtilis. 
Table 9

The increase in water absorption by weight values

\begin{tabular}{|c|c|c|c|c|c|c|c|c|c|}
\hline $\begin{array}{l}\text { Bacillus } \\
\text { species }\end{array}$ & Rock Type & $\begin{array}{l}\text { Reactor } \\
\text { No }\end{array}$ & NB & $\begin{array}{l}\text { Before test } \\
A_{w}(\%)\end{array}$ & $\sigma$ & $\begin{array}{l}\text { After test } \\
A_{w}(\%)\end{array}$ & $\sigma$ & $\begin{array}{l}\Delta \mathrm{A}_{\mathrm{w}} \\
(\%)\end{array}$ & $\mathbf{N}$ \\
\hline \multirow[t]{6}{*}{ B. subtilis } & \multirow[t]{2}{*}{ Granite } & 1 & + & 0.52 & 0.01 & 0.54 & 0.17 & -3.86 & 5 \\
\hline & & 2 & - & 0.41 & 0.06 & 0.46 & 0.04 & -11.43 & \\
\hline & \multirow[t]{2}{*}{ Andesite } & 3 & + & 5.13 & 0.17 & 4.63 & 0.30 & 9.81 & 5 \\
\hline & & 4 & - & 5.09 & 0.12 & 5.27 & 0.17 & -3.67 & \\
\hline & \multirow[t]{2}{*}{ Limestone } & 5 & + & 3.39 & 0.18 & 2.98 & 0.23 & 12.41 & 5 \\
\hline & & 6 & - & 3.55 & 0.12 & 3.31 & 0.11 & 6.80 & \\
\hline \multirow[t]{6}{*}{ B. pumilus } & \multirow[t]{2}{*}{ Granite } & 8 & + & 0.39 & 0.17 & 0.35 & 0.12 & 8.59 & 5 \\
\hline & & 9 & - & 0.39 & 0.08 & 0.48 & 0.04 & -28.41 & \\
\hline & \multirow[t]{2}{*}{ Andesite } & 10 & + & 5.27 & 0.10 & 4.77 & 0.17 & 9.54 & 5 \\
\hline & & 11 & - & 5.18 & 0.16 & 5.23 & 0.20 & -0.84 & \\
\hline & \multirow[t]{2}{*}{ Limestone } & 12 & + & 3.64 & 0.07 & 3.38 & 0.13 & 7.02 & 5 \\
\hline & & 13 & - & 3.27 & 0.14 & 3.55 & 0.21 & 0.57 & \\
\hline
\end{tabular}

\section{Sonic Velocity Results $\left(P_{\text {wave }}\right)$}

The results of sonic velocity measurements are given in Table 10. For $B$. subtilis experiments, the sonic velocity changes were higher in NB- condition. The effect of the presence of bacteria here was higher on granite and limestone samples than on andesite samples (Fig. 18). For B. pumilus experiments, NBcondition led to a higher difference in sonic velocities (Fig. 19). The maximum effect here was observed on the limestone. The decrease in sonic velocity was also observed for the granite sample at the end of the experiment (Table 10). With andesite and NB + conditions, excessive growth of bacterial colonies filled gaps on the sample surface and, therefore, an increase in the sonic speed was observed. In the NB-condition, changes were negligible. 
Table 10

Sonic velocity differences

\begin{tabular}{|c|c|c|c|c|c|c|c|c|c|}
\hline $\begin{array}{l}\text { Bacillus } \\
\text { species }\end{array}$ & Rock Type & $\begin{array}{l}\text { Reactor } \\
\text { No }\end{array}$ & NB & $\begin{array}{l}\text { Before } \\
\text { test } \\
P_{\text {wave }} \\
(\mathrm{m} / \mathrm{s})\end{array}$ & $\sigma$ & $\begin{array}{l}\text { After test } \\
\mathrm{P}_{\text {wave }}(\mathrm{m} / \mathrm{s})\end{array}$ & $\sigma$ & $\begin{array}{l}\Delta \mathrm{P}_{\text {wave }} \\
(\%)\end{array}$ & $\mathbf{N}$ \\
\hline \multirow{6}{*}{$\begin{array}{l}\text { B. } \\
\text { subtilis }\end{array}$} & \multirow[t]{2}{*}{ Granite } & 1 & + & 5771.33 & 530.96 & 5458.03 & 267.16 & -5.19 & \multirow[t]{2}{*}{5} \\
\hline & & 2 & - & 6389.20 & 1272.16 & 5611.51 & 1066.81 & -12.06 & \\
\hline & \multirow[t]{2}{*}{ Andesite } & 3 & + & 4786.42 & 51.05 & 4933.09 & 72.56 & 3.07 & \multirow[t]{2}{*}{5} \\
\hline & & 4 & - & 4806.05 & 94.62 & 4833.39 & 84.56 & 0.57 & \\
\hline & \multirow[t]{2}{*}{ Limestone } & 5 & + & 5588.11 & 587.48 & 5317.56 & 158.96 & -4.36 & \multirow[t]{2}{*}{5} \\
\hline & & 6 & - & 5202.27 & 88.82 & 4595.35 & 123.55 & -11.63 & \\
\hline \multirow{6}{*}{$\begin{array}{l}\text { B. } \\
\text { pumilus }\end{array}$} & \multirow[t]{2}{*}{ Granite } & 8 & + & 6808.73 & 550.48 & 6190.00 & 361.48 & -8.97 & \multirow[t]{2}{*}{5} \\
\hline & & 9 & - & 6915.98 & 0464.33 & 5956.82 & 464.12 & -13.91 & \\
\hline & \multirow[t]{2}{*}{ Andesite } & 10 & + & 485390 & 55.72 & 5020.94 & 121.94 & 3.43 & \multirow[t]{2}{*}{5} \\
\hline & & 11 & - & 4778.90 & 18.94 & 4738.84 & 18.71 & -0.84 & \\
\hline & \multirow[t]{2}{*}{ Limestone } & 12 & + & 5290.09 & 439.77 & 5463.54 & 28.43 & 3.71 & \multirow[t]{2}{*}{5} \\
\hline & & 13 & - & 5298.94 & 420.52 & 4435.38 & 86.74 & -16.01 & \\
\hline
\end{tabular}

\section{Uniaxial Compressive Strength}

The following results were obtained by calculating the differences between the strength values measured at the beginning and end of each experiment. Accordingly, the change in the uniaxial compressive strength was more remarkable in the NB- condition compared to the NB + condition in reactors, including $B$. subtilis (Fig. 20-21). This indicates that adding growth media to the reactors increased bacterial activity, yet reduced rock degradation. In reactors including B. pumilus, the percentage difference in the NB-condition for andesite and limestone samples were also higher than that in the NB + condition. For granite, the opposite of this effect was observed. B. pumilus colonies mostly affected the strength of andesite samples, whereas $B$. subtilis reduced the strength of limestone and andesite samples. Bacterial colonies that settled in the cavities of andesite samples caused a decrease in the strength. Finally, since granite samples contain high amounts of quartz minerals and have very low porosity, they have been the least affected by bacterial Degradation (Table 11). 
Table 11

Uniaxial compressive strength measurement results before and after tests

\begin{tabular}{|c|c|c|c|c|c|c|c|c|c|}
\hline $\begin{array}{l}\text { Bacillus } \\
\text { species }\end{array}$ & Rock Type & $\begin{array}{l}\text { Reactor } \\
\text { No }\end{array}$ & NB & $\begin{array}{l}\text { *Before } \\
\text { test } \\
\sigma_{\mathrm{c}}(\mathrm{MPa})\end{array}$ & $\sigma$ & $\begin{array}{l}\text { After } \\
\text { test } \\
\sigma_{\mathrm{c}} \\
(\mathrm{MPa})\end{array}$ & $\sigma$ & $\begin{array}{l}\Delta \sigma_{\mathrm{c}} \\
(\%)\end{array}$ & $\mathbf{N}$ \\
\hline \multirow[t]{6}{*}{ B. subtilis } & \multirow[t]{2}{*}{ Granite } & 1 & + & 109.95 & 5.14 & 92.02 & 11.85 & -16.31 & \multirow[t]{2}{*}{5} \\
\hline & & 2 & - & 109.95 & 5.14 & 79.08 & 9.05 & -28.08 & \\
\hline & \multirow[t]{2}{*}{ Andesite } & 3 & + & 53.81 & 9.50 & 49.77 & 11.12 & -7.51 & \multirow[t]{2}{*}{5} \\
\hline & & 4 & - & 53.81 & 9.50 & 37.82 & 10.32 & -29.72 & \\
\hline & \multirow[t]{2}{*}{ Limestone } & 5 & + & 28.99 & 8.64 & 36.34 & 9.81 & 25.33 & \multirow[t]{2}{*}{5} \\
\hline & & 6 & - & 28.99 & 8.64 & 24.83 & 3.20 & -14.36 & \\
\hline \multirow[t]{6}{*}{ B. pumilus } & \multirow[t]{2}{*}{ Granite } & 8 & + & 109.95 & 5.14 & 81.26 & 30.65 & -26.09 & \multirow[t]{2}{*}{5} \\
\hline & & 9 & - & 109.95 & 5.14 & 115.55 & 9.85 & 5.09 & \\
\hline & \multirow[t]{2}{*}{ Andesite } & 10 & + & 53.81 & 9.50 & 43.10 & 6.46 & -19.90 & \multirow[t]{2}{*}{5} \\
\hline & & 11 & - & 53.81 & 9.50 & 38.16 & 8.42 & -29.09 & \\
\hline & \multirow[t]{2}{*}{ Limestone } & 12 & + & 28.99 & 8.64 & 31.83 & 1.55 & 9.77 & \multirow[t]{2}{*}{5} \\
\hline & & 13 & - & 28.99 & 8.64 & 28.40 & 1.23 & -2.05 & \\
\hline
\end{tabular}

\section{Colour Changes}

Results of colour changes and variations in reactors are presented in Table 12. In NB + reactors, the colour change was more significant than those observed in NB- reactors. For both B. pumilus and B. subtilis, colour change in granite samples was higher compared to other rock types. On the other hand, both B. pumilus, as well as B. subtilis, caused the same level of colour change in andesite samples. The colour change of the limestone sample was also more significant with B. subtilis compared to B. pumilus. 
Table 12

Colour change results

\begin{tabular}{|c|c|c|c|c|c|c|}
\hline Bacillus species & Rock Type & $\begin{array}{l}\text { Reactor } \\
\text { No }\end{array}$ & NB & Colour Difference & $\sigma$ & $\mathbf{N}$ \\
\hline \multirow[t]{6}{*}{ B. subtilis } & \multirow[t]{2}{*}{ Granite } & 1 & + & 109.95 & 5.14 & \multirow[t]{2}{*}{5} \\
\hline & & 2 & - & 109.95 & 5.14 & \\
\hline & \multirow[t]{2}{*}{ Andesite } & 3 & + & 53.81 & 9.50 & \multirow[t]{2}{*}{5} \\
\hline & & 4 & - & 53.81 & 9.50 & \\
\hline & \multirow[t]{2}{*}{ Limestone } & 5 & + & 28.99 & 8.64 & \multirow[t]{2}{*}{5} \\
\hline & & 6 & - & 28.99 & 8.64 & \\
\hline \multirow[t]{6}{*}{ B. pumilus } & \multirow[t]{2}{*}{ Granite } & 8 & + & 109.95 & 5.14 & \multirow[t]{2}{*}{5} \\
\hline & & 9 & - & 109.95 & 5.14 & \\
\hline & \multirow[t]{2}{*}{ Andesite } & 10 & + & 53.81 & 9.50 & \multirow[t]{2}{*}{5} \\
\hline & & 11 & - & 53.81 & 9.50 & \\
\hline & \multirow[t]{2}{*}{ Limestone } & 12 & + & 28.99 & 8.64 & \multirow[t]{2}{*}{5} \\
\hline & & 13 & - & 28.99 & 8.64 & \\
\hline
\end{tabular}

\section{Scanning Electron Microscopy}

SEM imaging results were classified according to rock groups. Images of each rock type were taken in NB + and NB-conditions for $B$. subtilis and $B$. pumilus. Voids on minerals were preferred for imaging since bacteria tend to occupy scratches and voids on rock surfaces. Each sample was photographed at 500 magnifications to mark and highlight areas for imaging. Variations observed on surfaces before and after each experiment were circled, and the results are given below.

\section{Granite}

The G-1 sample included $B$. subtilis under NB + condition. The photos of biotite, quartz, alkali feldspar, magnetite were taken on granite samples. In the G-1 sample, no change was found on quartz and magnetite minerals. Under NB + conditions, bacteria were determined not to form tight biofilms on biotite, yet still tend to cling to surfaces. Here, changes on the surface are observed. B. subtilis also clinged to alkali feldspar and occupied cracks under NB + condition. No biofilms were observed on quartz, biotite, alkali feldspar and magnetite minerals in the G-2 sample. The reason for the absence of biofilms here may be the lack of growth media (NB- conditions). Unclear morphological changes were observed on biotite. Here, observations at higher magnifications were not possible due to the lack of coating and the necessity of imaging under low vacuum. The G-3 sample included B. pumilus under NB + condition. In this sample, photos were taken 
for quartz, biotite, alkali feldspar and magnetite minerals. Longitudinal traces of organic material were detected on the biotite, which converged toward the centre of the image. Since these traces indicate carbon content, they may also indicate bacterial growth. Biofilm was observed on quartz. G-4 sample included $B$. pumilus under NB- condition. In this sample, photos were taken for quartz, biotite, alkali feldspar and magnetite minerals. Traces of organic compound content was observed on quartz. Organic material traces were also detected on biotite minerals (Fig. 22).

\section{Andesite}

The A-1 andesite sample included $B$. subtilis under the NB + condition. In this sample, photos were taken for quartz, amphibole minerals and cavities in the matrix. Biofilm formation was observed on quartz and the pores. Although no biofilm was found on the amphibole at the end of the experiment, organic compound residues were detected. A-2 sample included $B$. subtilis in the NB- condition. In this sample, photos were taken for quartz, amphibole minerals and cavities in the matrix. Although $B$. subtilis cells did not form biofilms in the NB- condition here, they still caused alterations on the quartz surface. No biofilm was found on the pores. A-3 sample included B. pumilus in the NB + condition. In this sample, photos were taken for quartz, feldspar minerals and cavities in the matrix. Under NB + condition, $B$. pumilus formed biofilm on quartz minerals. No biofilm was found in the pores and on feldspar minerals. A-4 sample included $B$. Pumilus in the NB- condition. Under NB- condition, B. pumilus formed organic residues on long arms of the quartz minerals. No biofilms were found in the pores. Although there is no biofilm on feldspar, it was still possible to observe bacterial colonies on the quartz minerals (Fig. 22).

\section{Limestone}

The K-1 sample included $B$. subtilis under the NB + condition. At the end of the experiment, organic residues were found in the pores and on the surfaces of the minerals of this sample. $\mathrm{K}-2$ sample included $B$. subtilis in the NB- condition. Here, a small amount of organic residue was observed on the sample surface at the end of the experiment. $\mathrm{K}-3$ sample included $B$. pumilus under the NB + condition. Alterations in pores were observed at the end of the experiment. K-4 sample included B. pumilus in the NB- condition. Here, deteriorations in pores were also observed (Fig. 22).

\section{Optical Density and Water Chemistry Analysis}

\section{Optical Density Results}

According to the optical density measurement results, $B$. subtilis adapted to the NB + reactor condition within 24 hours and reached a peak in optical density within five days. This point denotes the maximum number of cells. Compared to control reactor with no rock sample and only the growth medium, bacterial growths in all other reactors were characterised with increasing and decreasing absorbance measurements.

The initial increase in absorbance values for each sample represents the adaptation of the bacteria to the reactor environment. Above-average increases in absorbance were evaluated as time periods in which bacteria preferred to utilise the mineral contained in the sample as a nutrient for growth. The increase in absorbance with the granite sample may be related to the increase in the use of biotite and quartz as nutrients. Likewise, the second increase in absorbance with the andesite sample may be related to biofilm 
formation on quartz, amphibole, and paste. The absorbance increase with limestone is considered to be due to the calcite mineral content (Fig. 23).

B. pumilus adapted to NB + conditions within 24 hours, whereas $B$. pumilus growth reached a peak within 11 days. In limestone, the increase in bacterial growth occurred earlier compared to other reactors. Here, calcium carbonate may have exerted a positive effect on bacterial growth. The increase in the absorbance measurements of the granite may again be related to the increase in the use of biotite and quartz as nutrients. The late increase in andesite sample may also be related to biofilm formation on quartz, amphibole and paste (Fig. 24).

\section{Water Chemistry Analysis}

Water chemistry analysis was performed to monitor chemical composition changes in the reactor liquid. The results are presented in Figs. 27 and 28, where "B Control" denotes the reactor where B. subtilis or $B$. pumilus was included in NB + condition without any rock samples, and "B NB" denotes the reactor including only growth media for $B$. subtilis or $B$. pumilus. Elemental analyses including $\mathrm{Mg}, \mathrm{Mn}, \mathrm{Si}, \mathrm{Ca}, \mathrm{Fe}, \mathrm{Zn}, \mathrm{S}, \mathrm{Na}, \mathrm{P}$, $\mathrm{K}, \mathrm{Ni}, \mathrm{Cu}, \mathrm{Cr}$, Al were performed for $B$. subtilis experiments. The chemical composition of the nutrient (NB) solution after removing bacteria and the chemical composition of the nutrient solution taken from the control reactor at the end of the experiment were compared to each other. The presence of $B$. subtilis was found to decrease the concentration of $\mathrm{Mg}$ and $\mathrm{Mn}$, whereas it caused an increase in the concentration of $\mathrm{Si}, \mathrm{Ca}, \mathrm{Fe}, \mathrm{Zn}, \mathrm{S}, \mathrm{Na}, \mathrm{P}, \mathrm{K}, \mathrm{Ni}, \mathrm{Cu}, \mathrm{Cr}$, and $\mathrm{Al}$ elements. $\mathrm{Mg}$ content was increased in granite and andesite, whereas it decreased in limestone samples. Considering the SEM images of G-1 and A-1 samples, organic residues are considered to cause Degradation in biotite. Although Si content decreased in all reactors, the highest usage of Si from the reactor solution was obtained in reactors with limestone, and the lowest usage of $\mathrm{Si}$ was obtained in reactors with granite. The lowest amount of $\mathrm{Ca}$ increase occurred in the reactor with andesite samples. Although Fe and $\mathrm{Zn}$ content decreased in all reactors, the highest usage of $\mathrm{Fe}$ and $\mathrm{Zn}$ from the reactor solution was obtained in reactors with andesite, and the lowest usage of $\mathrm{Fe}$ and $\mathrm{Zn}$ was obtained in reactors with granite. Based on these results, it can be concluded that bacteria utilised some Fe and $\mathrm{Zn}$ from the biotite mineral instead of the solution. Although the $\mathrm{S}, \mathrm{Na}, \mathrm{P}$, and $\mathrm{K}$ contents decreased in each reactor, the lowest values were observed in reactors with andesite. Mn content decreased in reactors with granite and andesite and increased in reactors with limestone. Considering SEM images and apparent porosity values, it was concluded that there was a dissolution of limestone (Fig. 25).

The chemical composition of the NB solution without bacteria was compared with the chemical composition of the NB solution taken from the control reactor at the end of the experiment. Here, B. pumilus caused a decrease in $\mathrm{Mn}$ and an increase in $\mathrm{Ca}, \mathrm{Fe}, \mathrm{Zn}, \mathrm{Na}, \mathrm{K}$, and $\mathrm{Mg}$ elemental content. No change was observed in the concentration of $\mathrm{Si}$ and $\mathrm{P}$ elements. $\mathrm{Na}$ content increased in limestone and decreased in granite and andesite reactors. While $\mathrm{P}$ was released from granite and limestone, $\mathrm{P}$ content was decreased in andesite. The use of $\mathrm{K}$ mostly occurred mostly in andesite, followed by granite. No significant difference was observed for limestone. $\mathrm{Zn}$ content increased in granite and limestone, while it decreased in andesite. Highest Fe usage was in andesite (Fig. 26).

\section{Conclusions}


Based on the obtained results, the mineral types on which B. subtilis and B. pumilus are active were determined. Our considerations and recommendations for further studies are summarised below.

Although the presence of growth media (NB+) provided essential data for studying the growth of the bacteria on rocks, it also improves the conditions for the growth of bacteria. However, rock mechanics experiments clearly showed that rock degradation was higher in reactors with no growth media (NB-). This is because bacteria obtained nutrients essential for survival from rock minerals instead of the growth media. In addition, growth media entering into the pores on sample surfaces caused residues to form and resulted in erroneous results of apparent porosity, void ratio, water absorption by weight and sonic velocity tests. In the colour analysis, better results were obtained with NB + reactors; however, since NB is a coloured solution, further investigation is recommended.

SEM imaging was performed under low vacuum on uncoated samples. The low vacuum environment created problems with respect to obtaining clear and detailed images; however, coatings also expanded micropores. Since these images were focused on micropores, uncoated samples were preferred. For further studies, it is recommended to use both coated and uncoated samples for SEM imaging.

Performing water chemistry analysis on samples taken at the same time points as absorbance measurement samples may also be highly useful for better and more detailed interpretation of data, and to understand dynamic changes in chemical composition.

B. subtilis was found to be more effective on weathering of limestone and andesite, whereas B. pumilus was more effective on granite. These bacterial species caused degradation of rock samples even when no nutrients were in their environment. Here, increases in apparent porosity, void ratio and water absorption by weight in non-nutrient solutions, and sonic velocity, and decreases in uniaxial compressive strength were determined. In the presence of nutrients and growth media, decreases in apparent porosity, void ratio and water absorption by weight were detected, and sonic velocity and uniaxial compressive strength were found to be increased. The bacteria tended to settle in cracks and pores on rock sample surfaces. Bacterial Degradation of the granite rock was significant on quartz, biotite and alkali feldspar minerals. In the andesite rock, it was influential on quartz, alkali feldspar and amphibole minerals. $B$. subtilis also caused a more extensive colour change on limestone, whereas B. pumilus on granite. $\mathrm{Mg}, \mathrm{Mn}, \mathrm{Si}, \mathrm{Ca}, \mathrm{Fe}, \mathrm{Zn}, \mathrm{S}, \mathrm{N}, \mathrm{P}, \mathrm{K}$, $\mathrm{Ni}, \mathrm{Cu}, \mathrm{Cr}, \mathrm{Al}$ elements and $\mathrm{Zn}, \mathrm{Mn}, \mathrm{Fe}, \mathrm{Ni}, \mathrm{P}, \mathrm{K}, \mathrm{Ca}, \mathrm{Mg}$, Si elements were found to be essential in the process of microbial decomposition for $B$. subtilis and B. pumilus, respectively.

Biofilm coatings have been used to protect the surfaces of historical artefacts in recent years. The nutrient solution is also used in these coatings. The results obtained here showed that when the nutrients (i.e. growth media) enabling bacterial survival and growth are depleted, the bacteria begin to use the minerals of the rock to survive. Therefore, the effects of bacteria should also not be ignored when biofilms are used for surface protection in historical artefacts.

\section{Declarations}


This work was funded by Hacettepe University Research Funds (Project No. 08.01.602.005) and Hacettepe Technology Transfer Centre (HT-TTM). Bacteria were grown and maintained under appropriate environmental conditions in biological research laboratories of Hacettepe University Department of Environmental Engineering.

\section{References}

Adamo P, Violante P (2000) Weathering of rocks and neogenesis of minerals associated with lichen activity. Appl Clay Sci 16:229-256. https://doi.org/10.1016/S0169-1317(99)00056-3

ASTM 2845-08 (2017) Laboratory Determination of Pulse Velocities and Ultrasonic Elastic Constants of Rock Designation (American Society for Testing and Materials) Annual Book of ASTM Standards, Vol 18.12. ASTM International, USA

ASTM D 2244-16 (2017) Standard Practice for Calculation of Colour Tolerances and Colour Differences from Instrumentally Measured Colour Coordinates (American Society for Testing and Materials), 2016 Annual Book of ASTM Standards, Vol 06.01. ASTM International, USA

Beavis, FC (1985) Engineering Geology. Blackwell, London

Benardini J N, Sawyer J, Venkateswaran K, Nicholson W L (2003) Spore UV and acceleration resistance of endolithic Bacillus Pumilus and B Subtilis isolates obtained from Sonoran Desert basalt: Implications for lithopanspermia. Astrobiology 3(4):709-717https://doi.org/10.1089/153110703322736033

Binal A (2009) A new laboratory rock test based on freeze-thaw using a steel chamber. Q J Eng Geol Hydrogeol 42(2):179-198 https://doi.org/10.1144/1470-9236/08-040

Binal A (2019) The effect of wind pressure on surface erosion of soft rocks in arid regions. Bull Eng Geol Environ 78:1565-1574 https://doi.org/10.1007/s10064-017-1218-x

Cockell C S (2011) Biological Volcanic Rock Weathering In: Reitner J, Thiel V (eds) Encyclopaedia of Geobiology Encyclopaedia of Earth Sciences Series Springer. Dordrecht https://doi.org/10.1007/978-14020-9212-1_219

Costerton J W, Lewandowski Z, DeBeer D, Caldwell D E, Korber D R, James G A (1994) Biofilms, the customised microniche. J Bacteriol 176:2137-2142 https://doi.org/10.1128/jb.176.8.2137-2142.1994

Daryono L R, Titisari A D, Warmada I W, Kawasaki S (2019) Comparative characteristics of cement materials in natural and artificial beach rocks using a petrographic method. Bull Eng Geol Environ 78:3943-3958 https://doi.org/10.1007/s10064-018-1355-x

de Oliveira Frascá M H B, Del Lama E A (2018) Biological Weathering In: Bobrowsky PT, Marker B (eds) Encyclopedia of Engineering Geology Encyclopedia of Earth Sciences Series Springer, Cham https://doi.org/10.1007/978-3-319-73568-9_29 
Ehrlich H L (2002) Geomicrobiology. 4th Ed., Marcel Dekker, New York

Fajardo-Cavazos P, Nicholson W (2006) Bacillus endospores isolated from granite: Close molecular relationships to globally distributed Bacillus spp. from endolithic and extreme environments. Appl Environ Microbiol 72(4):2856-2863 https://doi.org/10.1128/AEM.72.4.2856-2863.2006

Fowler T A, Holmes P R, Crundwel FK (2001) On the kinetics and mechanism of the dissolution of pyrite in the presence of Thiobacillus ferrooxidans. Hydrometallurgy 59(2-3): 257-270 https://doi.org/10.1016/S0304-386X(00)00172-9

Gonzalez I, Laiz L, Hermosin B, Caballero B, Incerti C, Saiz-Jimenez C (1999) Bacteria isolated from rock art paintings: The case of Atlanterra shelter (south Spain) J Microbiol Methods 36:123-127 https://doi.org/10.1016/S0167-7012(99)00017-2

Gorbushina A A, Krumbein W (2005) Role of Microorganisms in Wear Down of Rocks and Minerals. In: Varma A., Buscot F. (eds) Microorganisms in Soils: Roles in Genesis and Functions. Soil Biology, vol 3. Springer, Berlin, Heidelberg. https://doi.org/10.1007/3-540-26609-7_3

Gupta A S, Rao S K (2001) Weathering indices and their applicability for crystalline rocks. Bull Eng Geol Environ 60(3):201-221 https://doi.org/10.1007/s100640100113

Heidari M, Momeni A A, Naseri F (2013) New weathering classifications for granitic rocks based on geomechanical parameters. Eng Geol https://doi.org/10.1016/j.enggeo.2013.08.007

Hoek E, Brown E T (1980) Underground excavations in rock. Institute of Mining and Metallurgy, London.

ISRM (2015) In the ISRM Suggested Methods for Rock Characterization, Testing and Monitoring: 20072014. Springer https://doi.org/10.1007/978-3-319-07713-0

Johnson R B, Degaff J V (1988) Principles of Engineering Geology. John Wiley Sons, New York

Kalinowski B E, Liermann L J, Givens S, Brantley SL (2000) Rates of bacteria-promoted solubilisation of Fe from minerals: A review of problems and approaches. Chem Geol 169:357-

370https://doi.org/10.1016/S0009-2541(00)00214-X

Lee J U, Fein J B (2000) Experimental study of the effects of Bacillus subtilis on gibbsite dissolution rates under near-neutral pH and nutrient-poor conditions. Chem Geol 166:193-202https://doi.org/10.1016/S00092541(99)00191-6

Li L, Tan Y, Huang B, Deng X (2020) Pore property as an indicator of macro-deterioration in slightly weathered tuffs. Eng Geol 105492 https://doi.org/10.1016/j.enggeo.2020.105492

Milanesi C, Baldi F, Vignani R, Ciampolini F, Faleri C, Cresti M (2006) Fungal deterioration of medieval wall fresco determined by analysing small fragments containing copper. Int Biodeterior Biodegrad 57(1):7-13 https://doi.org/10.1016/j.ibiod.2005.10.002 
Sousa L M O, Suárez del Río L M, Calleja L, Ruiz de Argandoña V G, Rodríguez Rey A (2005) Influence of microfractures and porosity on the physico-mechanical properties and weathering of ornamental granites Eng Geol 77:153-168 https://doi.org/10.1016/j.enggeo.2004.10.001

Stassi A, Zanardini E, Cappitell F, Schiraldi A, Sorlini C (1998) Calorimetric investigations on the metabolism of Bacillus strains isolated from artistic stoneworks. Ann Microbiol Enzymol 48:111-120

Štyriaková I, Štyriak I, Kraus I, Hradil D, Grygar T, Bezdička P (2003) Biodestruction and deferritization of quartz sands by Bacillus species. Miner Eng 16:709-713https://doi.org/10.1016/S0892-6875(03)00165-1

Song W, Ogawa N, Hatta T, Oguchi C T, Matsukura Y (2007) Effect of Bacillus subtilis on granite weathering: A laboratory experiment. Catena 70, 275-281.https://doi.org/10.1016/j.catena.2006.09.003.

Song W, Ogawa N, Takashima-Oguchi C, Hatta T, Matsukura Y (2010) Laboratory experiments on bacterial weathering of granite and its constituent minerals. Géomorphologie 4:327336.https://doi.org/10.4000/geomorphologie.8038

Sun H J, Imre Friedmann E (1999) Growth on geological time scales in the Antarctic cryptoendolithic microbial community. Geomicrobiol J 16:193- 202 https://doi.org/10.1080/014904599270686

Temiz A (1996) Genel Mikrobiyoloji laboratuvar yöntemleri. Hatiboğlu yayınları, Ankara (In Turkish)

Todar K (2020) The genus bacillus Todar's online textbook of bacteriology. http://www.textbookofbacteriology.net/Bacillus_6.html. Accessed 2 Jan 2020

Turtura G C, Perfetto A, Lorenzelli P (2000) Microbiological investigation on black crusts from open-air stone monuments of Bologna (Italy) New Microbiologica 23:207-228

Wu Y-wen, Zhang J-chi, Wang L-jian, Wang Y-xiang (2017) A rock-weathering bacteria isolated from rock surface and its role in ecological restoration on exposed carbonate rocks. Ecol Eng 101:162-169 https://doi.org/10.1016/j.ecoleng.2017.01.023

\section{Figures}




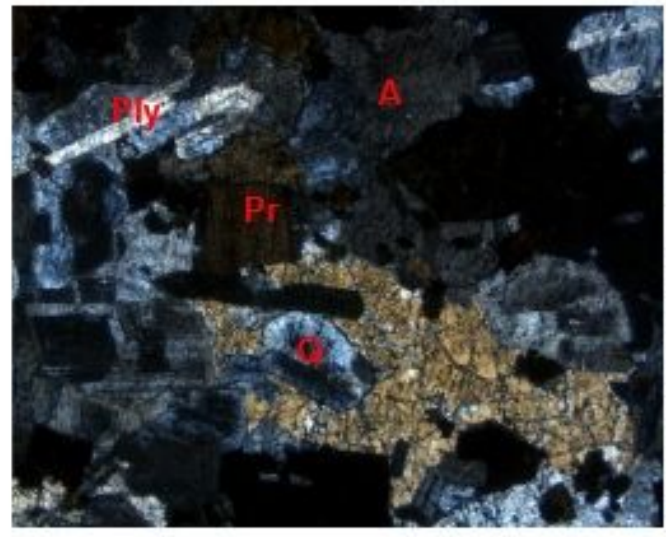

(a)

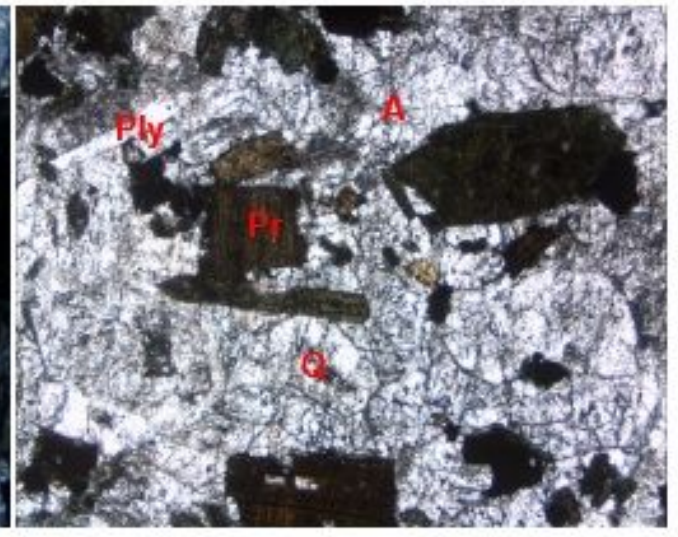

(b)

\section{Figure 1}

Thin section views of granite samples (Q: Quartz, Ply: Plagioclase; A: Amphibole; Pr: Pyroxene) a) Two Nicols b) One Nicol

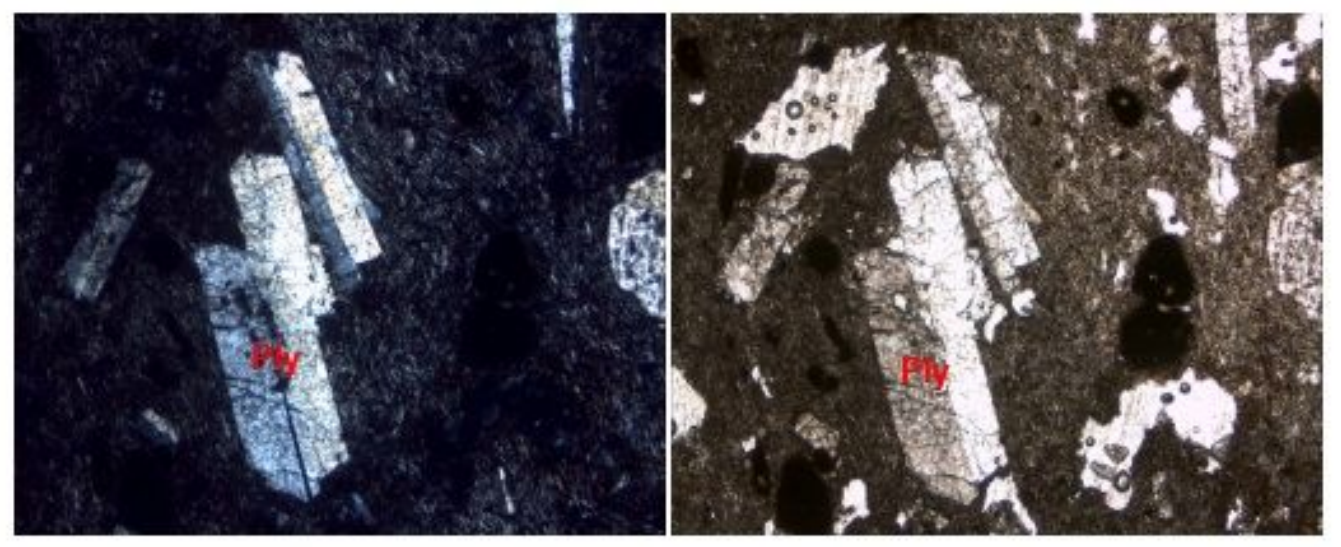

\section{Figure 2}

Thin section views of andesite sample (Ply: Plagioclase): a) Two Nicols b) One Nicol

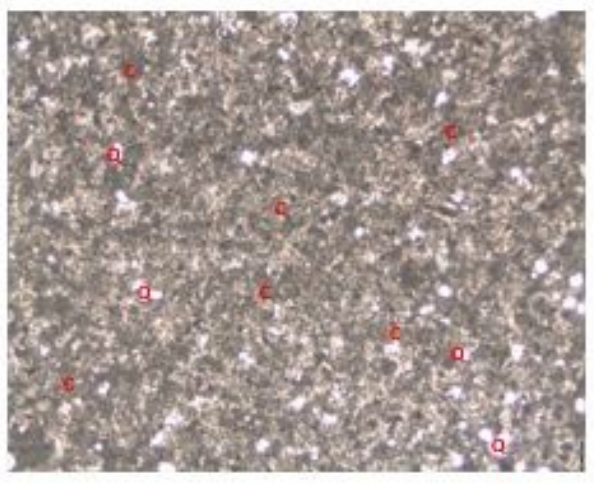

\section{Figure 3}

The thin section view of the limestone sample (one Nicol). Q: Quartz, C: Calcite 


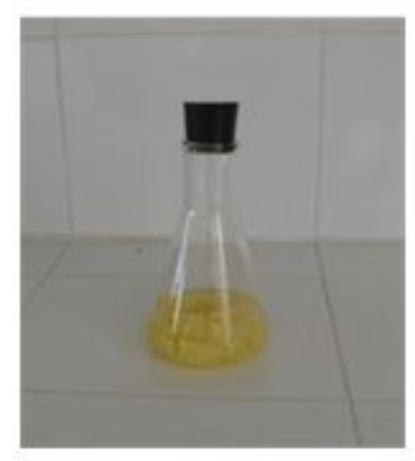

Figure 4

Potato extract medium

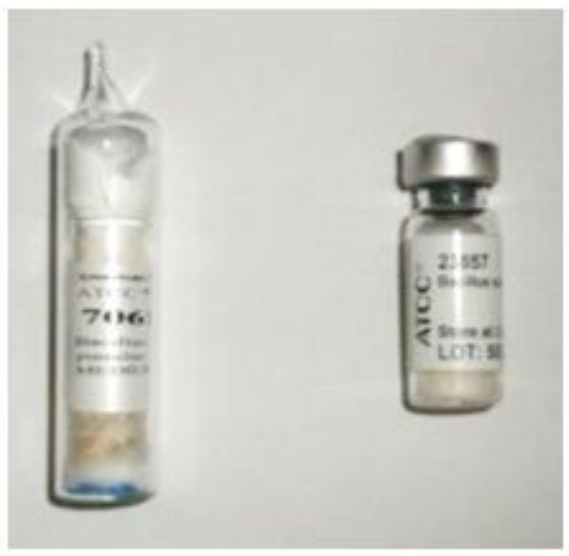

Figure 5

B. pumilus (left) and B. subtilis (right) in glass ampoules

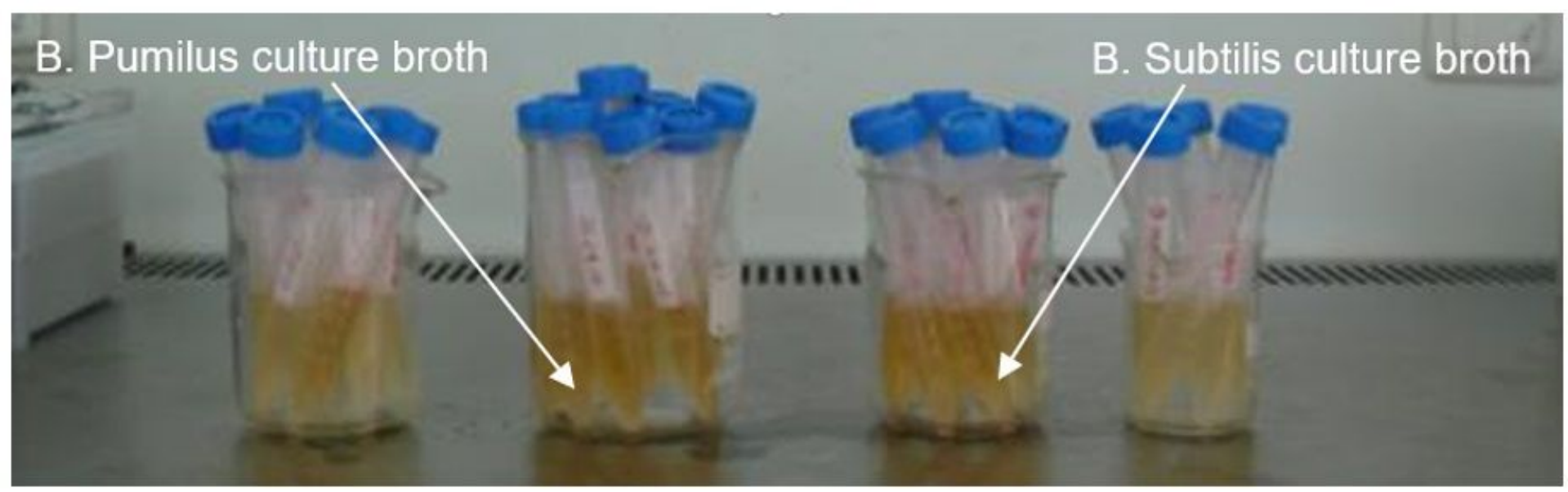

Figure 6

Liquid growth media 


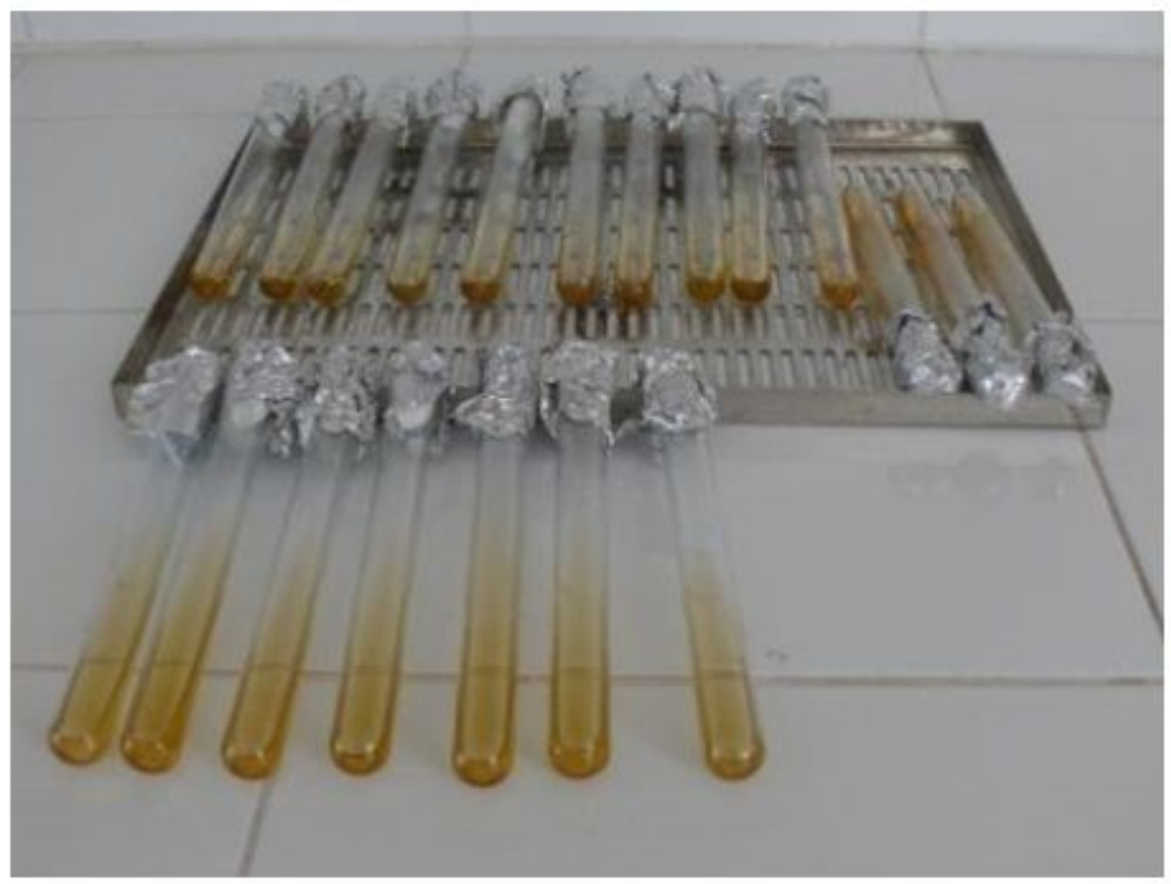

Figure 7

$5 \mathrm{ml}$ of solid medium

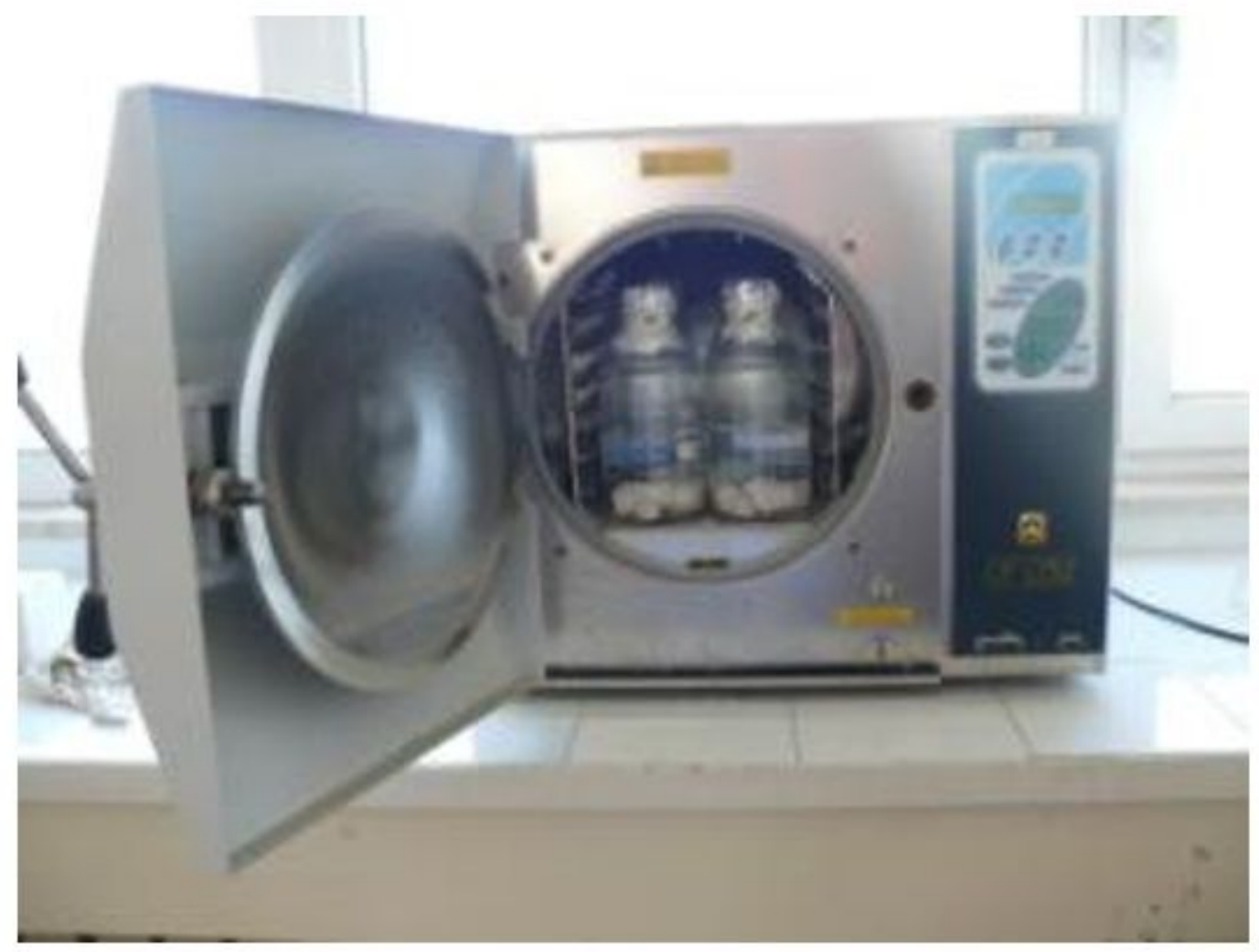

Figure 8

Reactors in the autoclave 


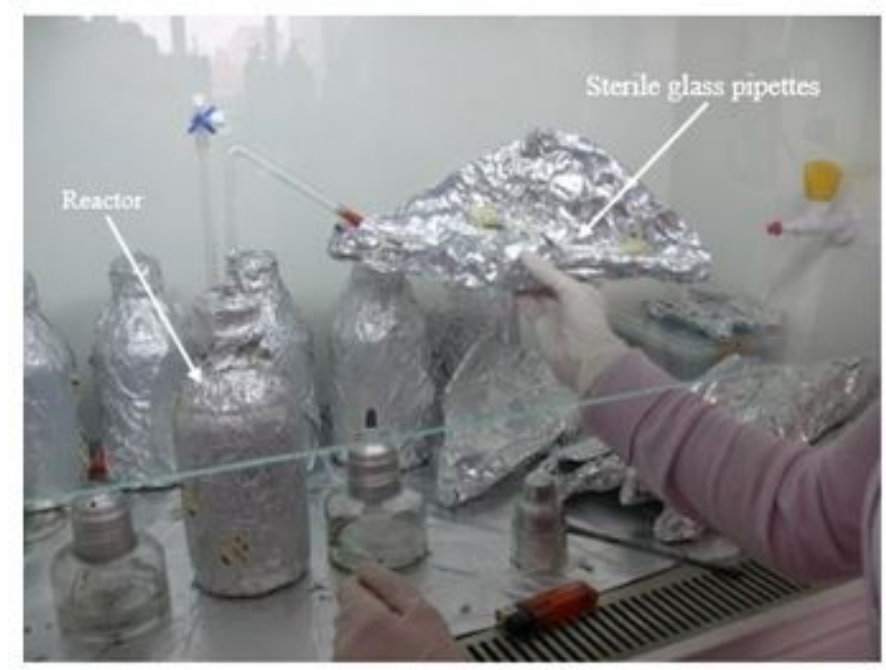

Figure 9

Reactor was assembled under the sterile hood

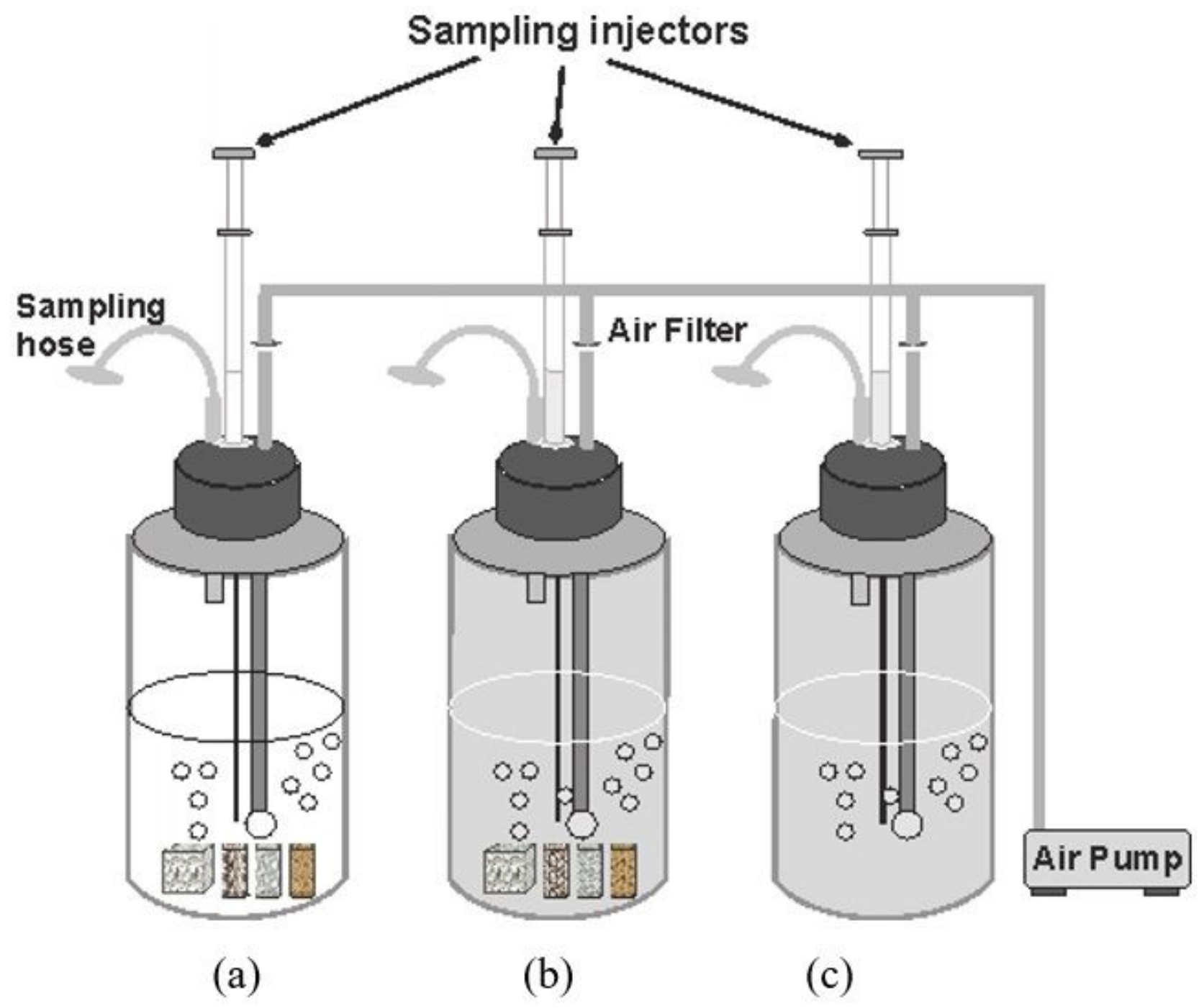




\section{Figure 10}

The reactors used in the experiments. Setup of the experiment. a) samples in the bacterium solution without nutrient extract, b) samples in the bacterium solution with nutrient extract (2.3 wt.\%), c) only, bacterium culture in nutrient broth solution

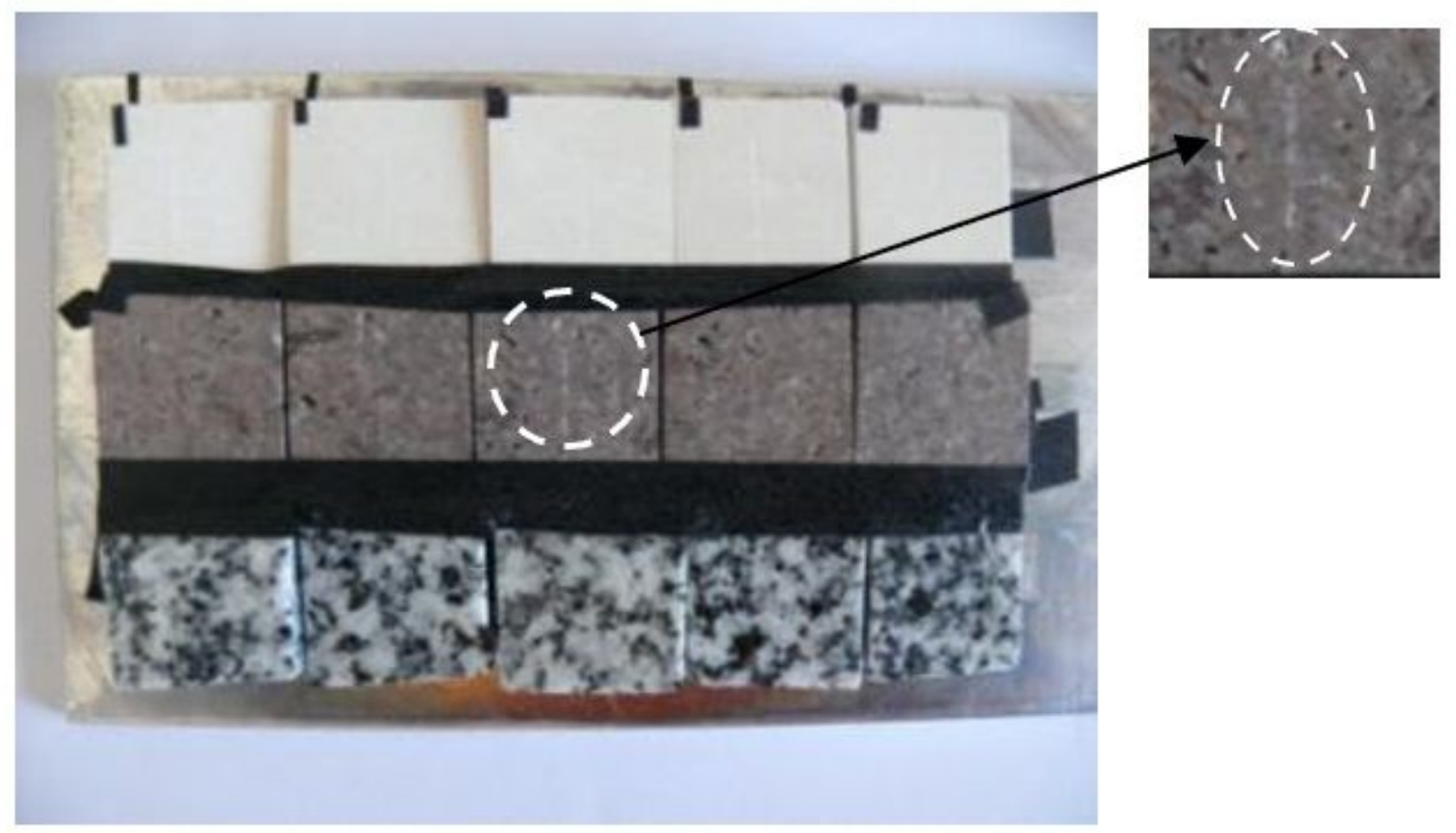

\section{Figure 11}

SEM imaging of the plate fastened to the samples and the reference point 


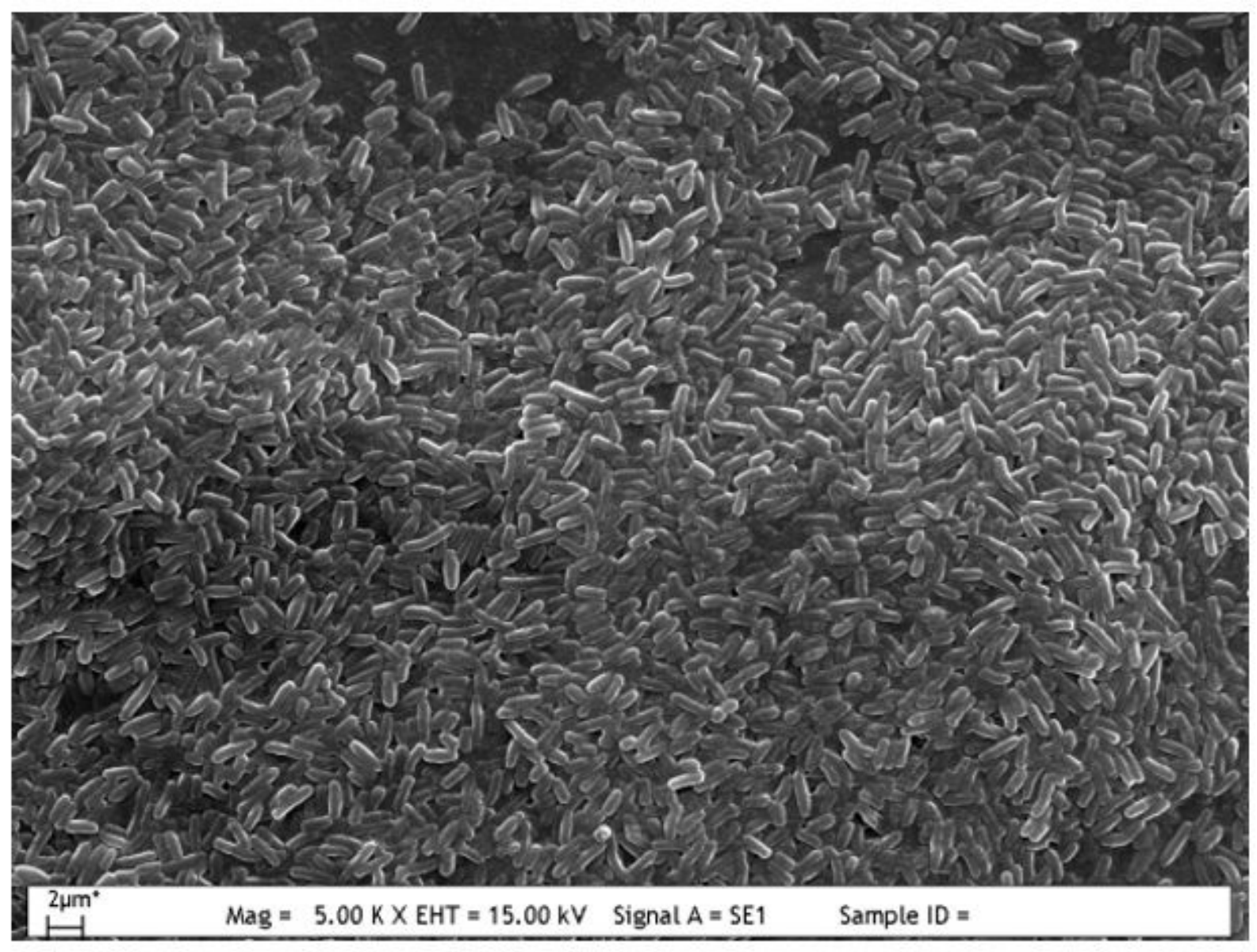

Figure 12

SEM image of B. subtilis 


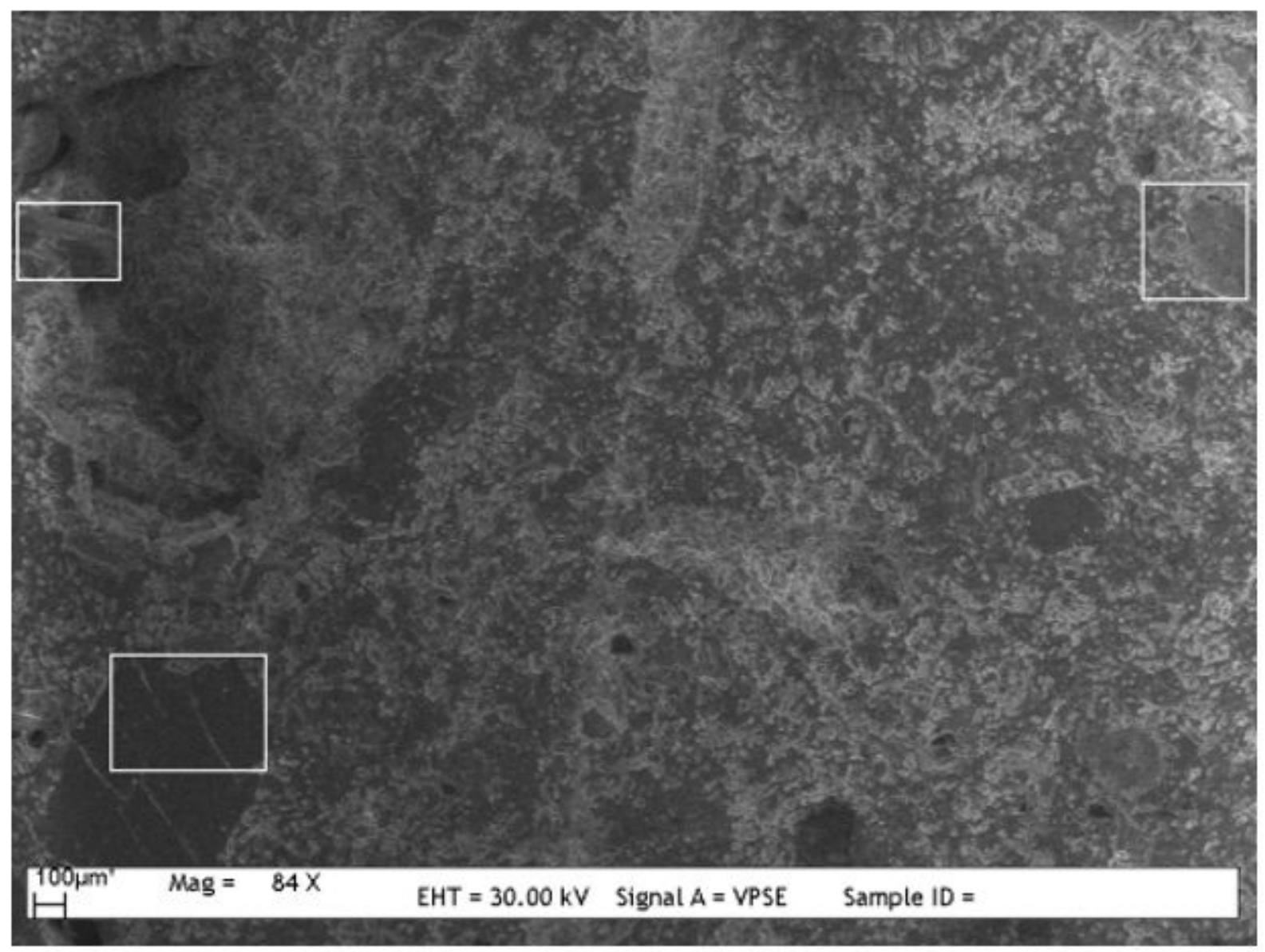

\section{Figure 13}

Andesite-1 markings on the SEM image (white-line rectangle).

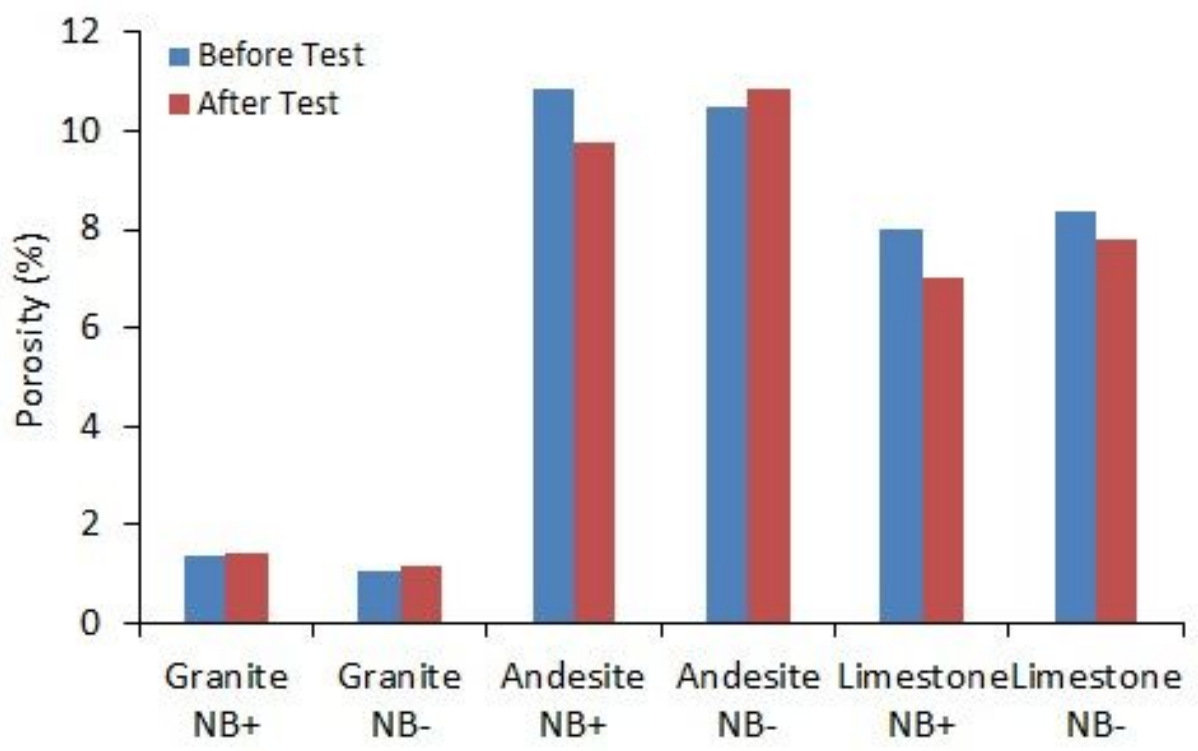

Figure 14

Apparent porosity graph for B. subtilis experiments 


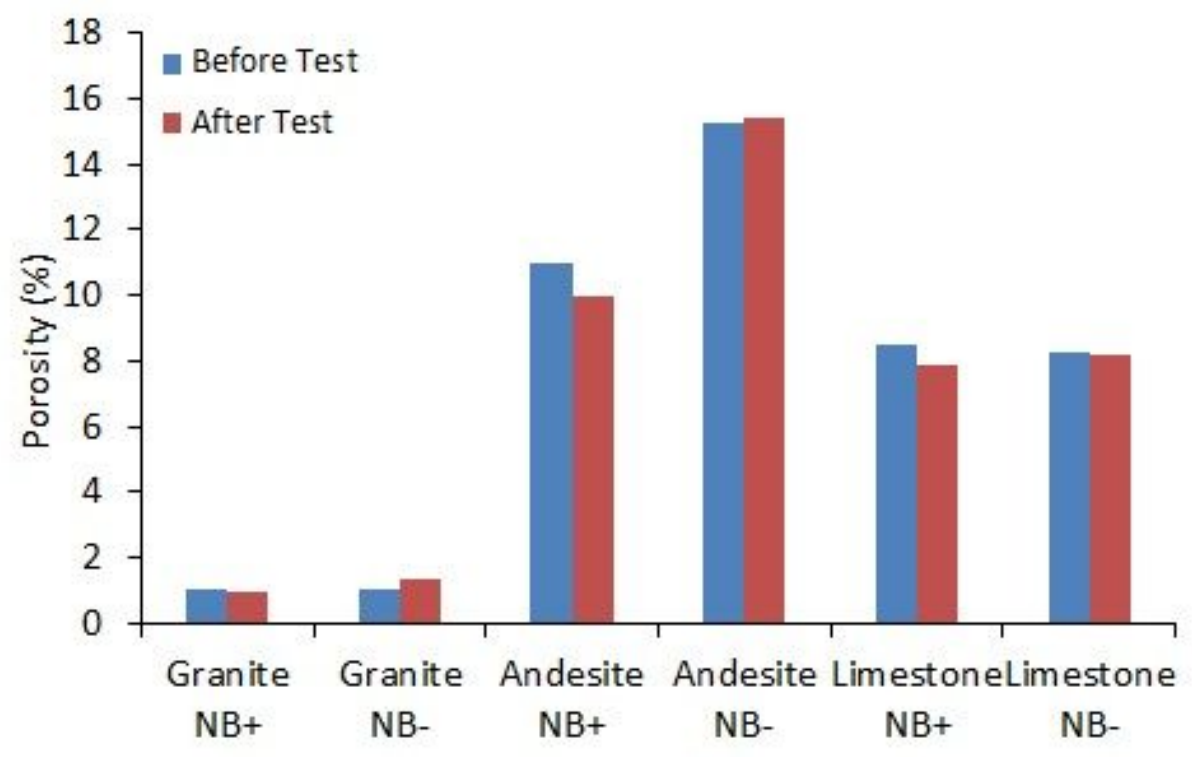

Figure 15

The apparent porosity difference graph for B. pumilus experiments

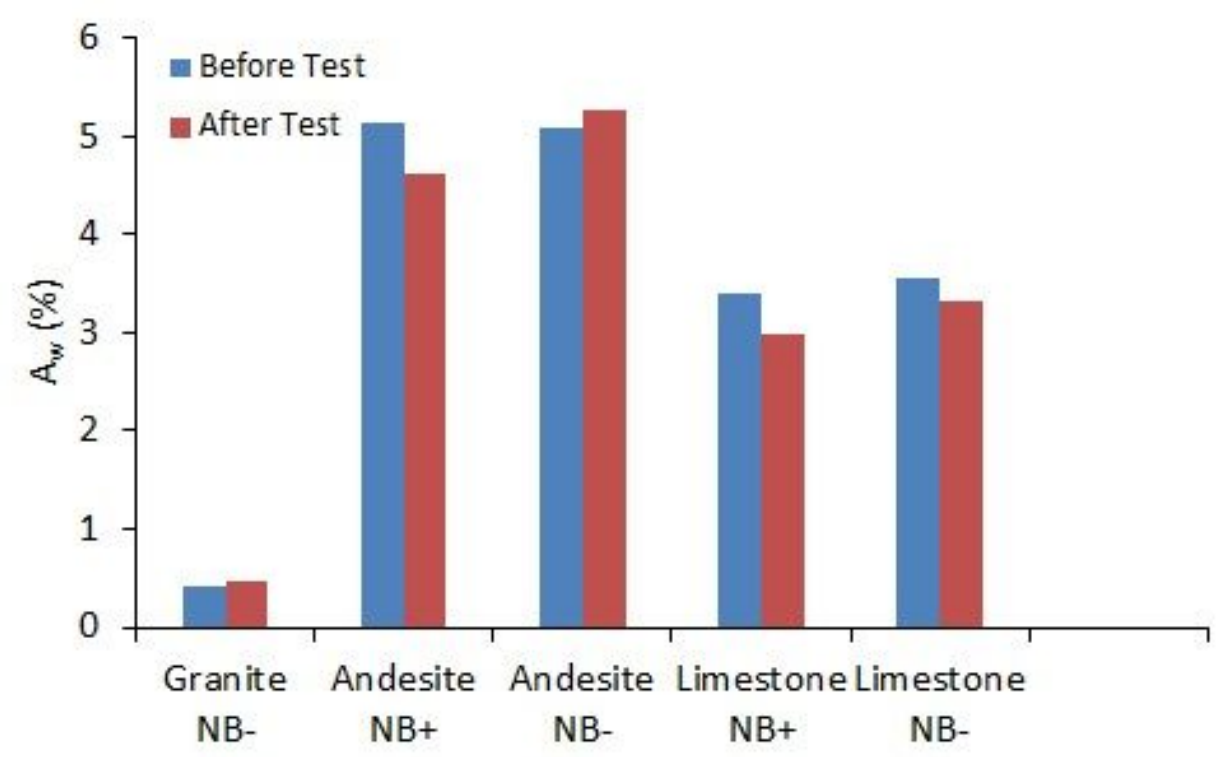

Figure 16

Water absorption by weight chart for B. subtilis experiments 


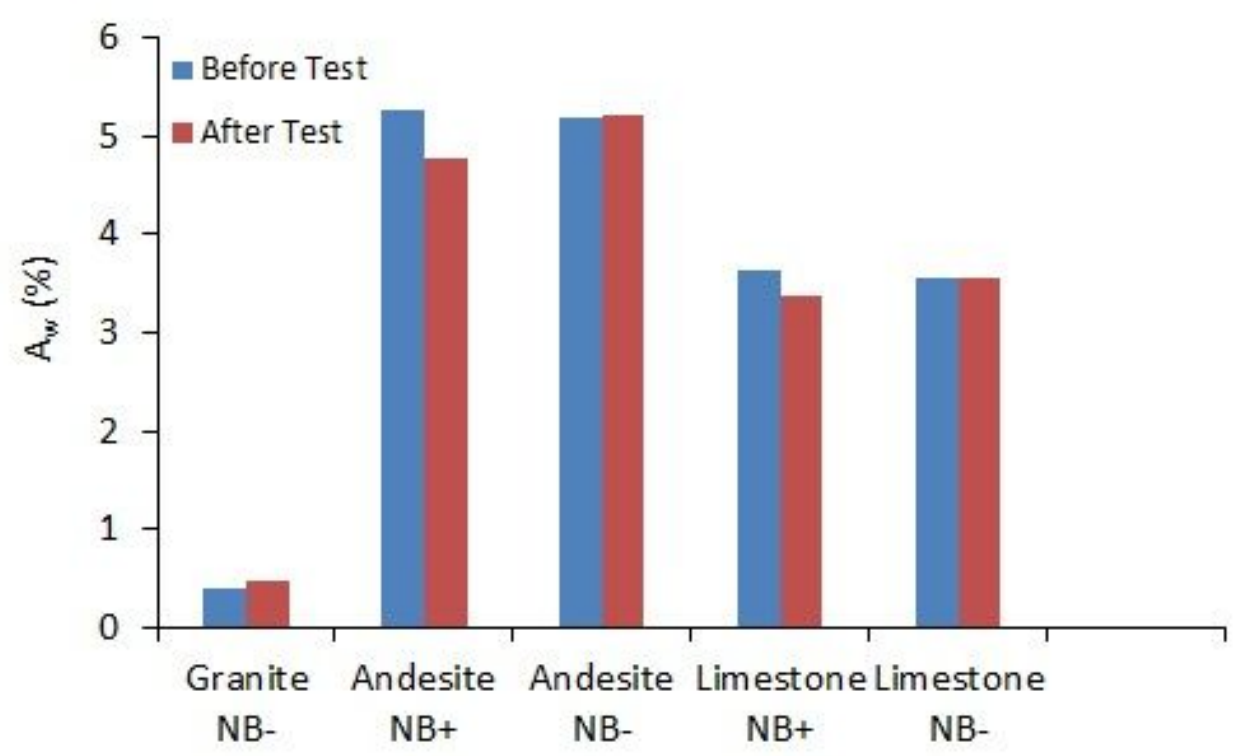

Figure 17

Water absorption by weight difference for B. pumilus experiments

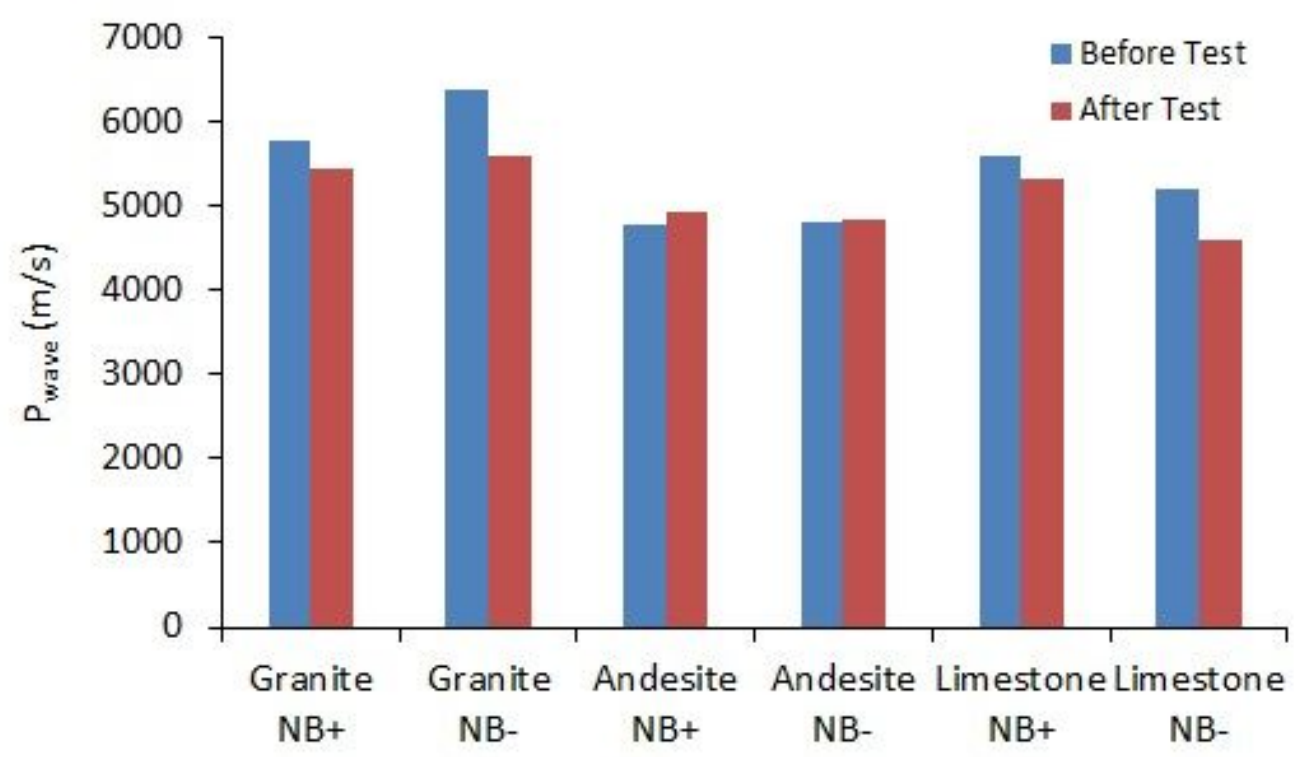

Figure 18

Sonic velocity measurement results for $\mathrm{B}$. subtilis experiments 


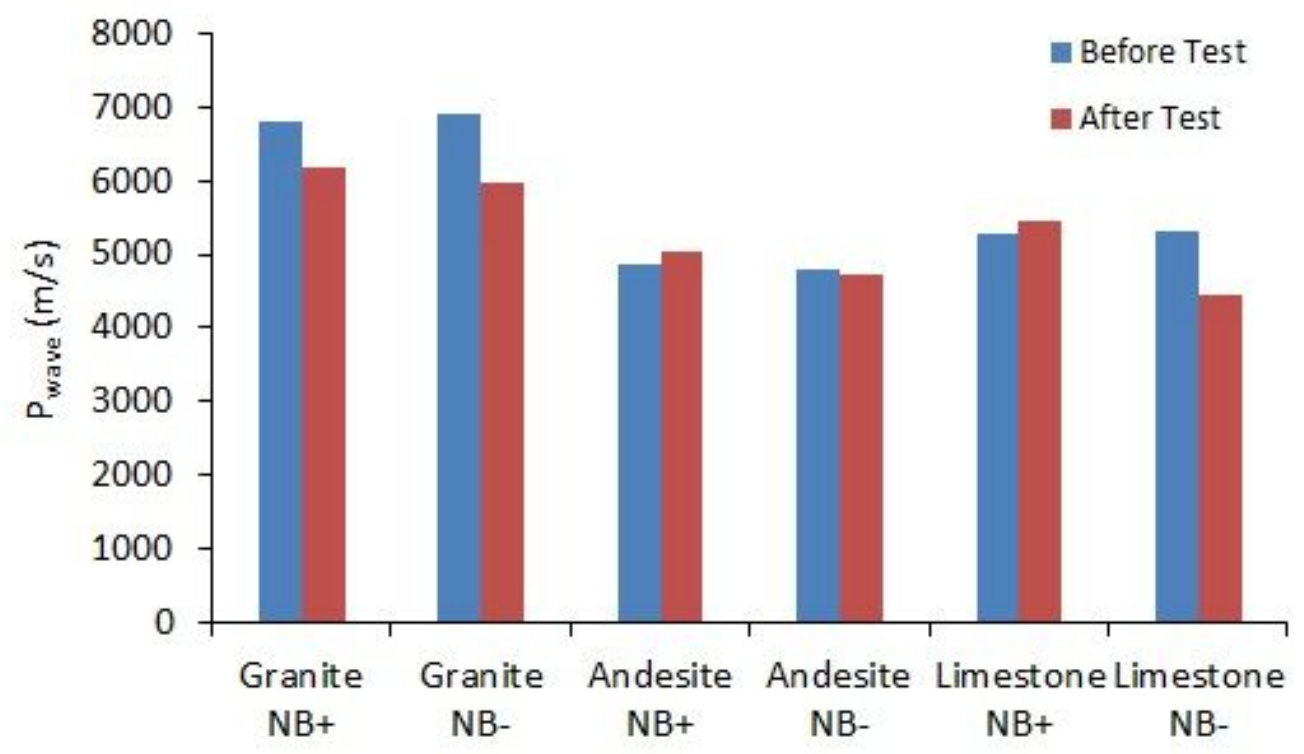

Figure 19

Sonic velocity measurement results for B. pumilus experiments

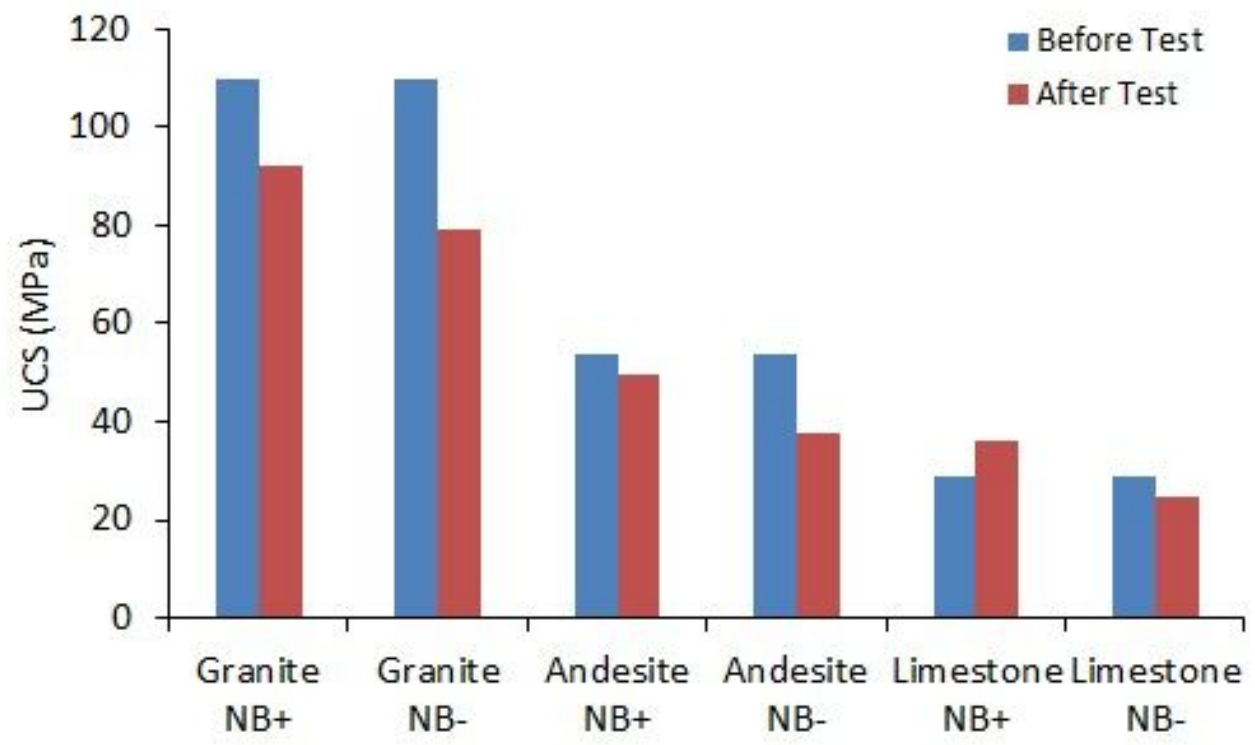

Figure 20

Uniaxial compressive strengths for B. subtilis and experiments 


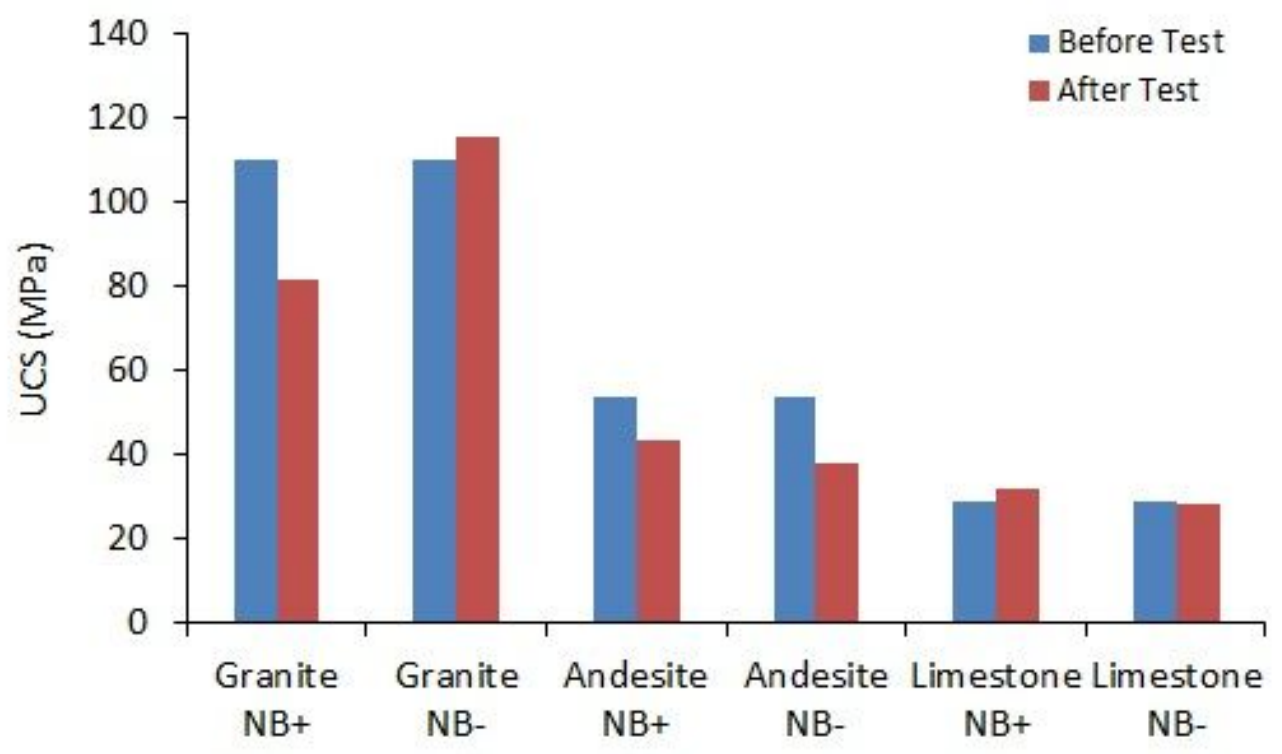

Figure 21

Uniaxial compressive strengths for B. pumilus experiments

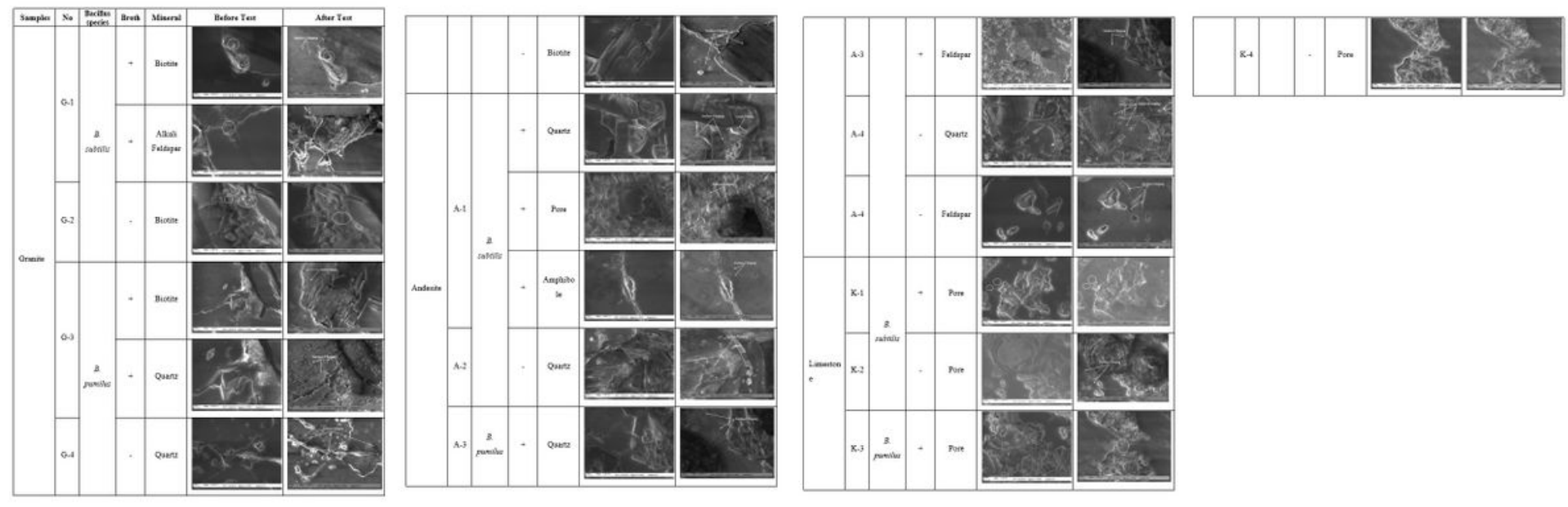

Figure 22

SEM images obtained before and after tests 


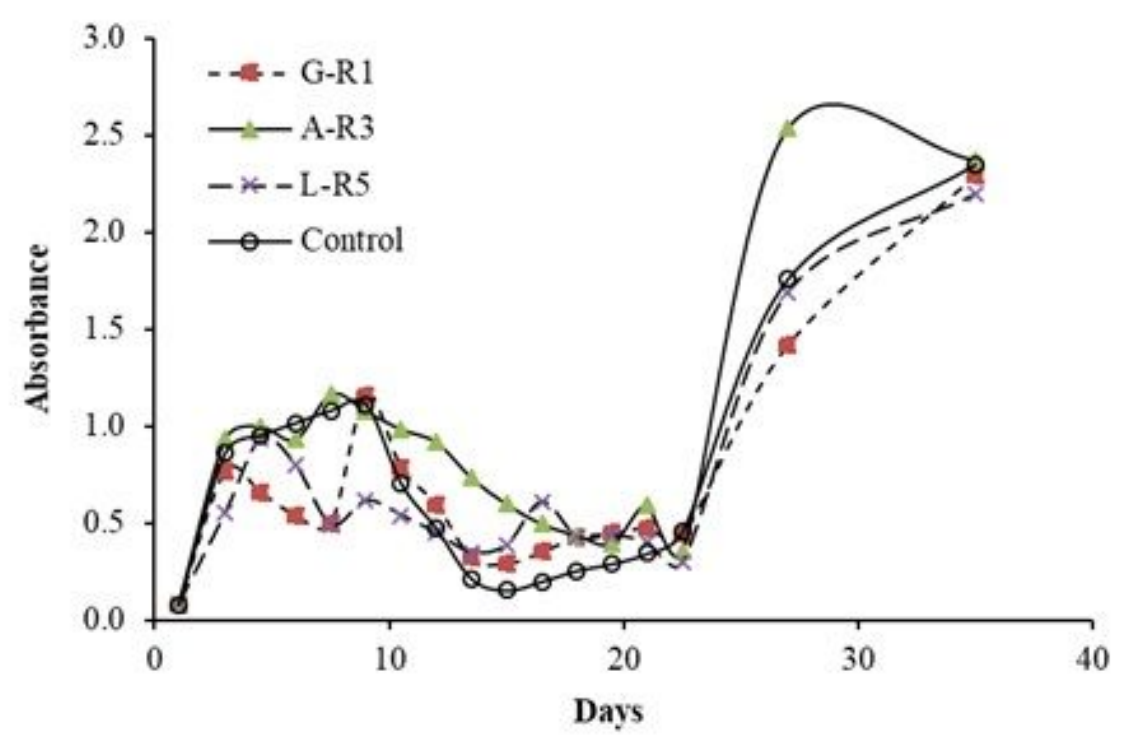

Figure 23

The optical density measurement results for reactors, including $B$. subtilis

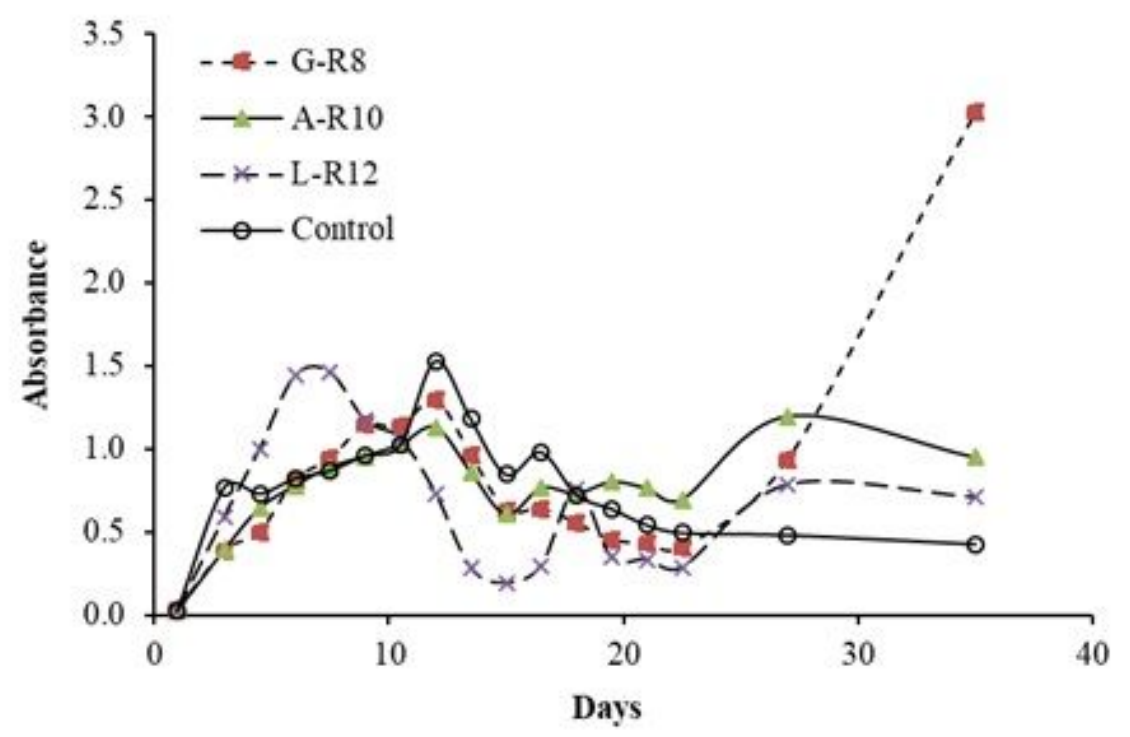

Figure 24

The optical density measurement results for reactors, including B. pumilus 


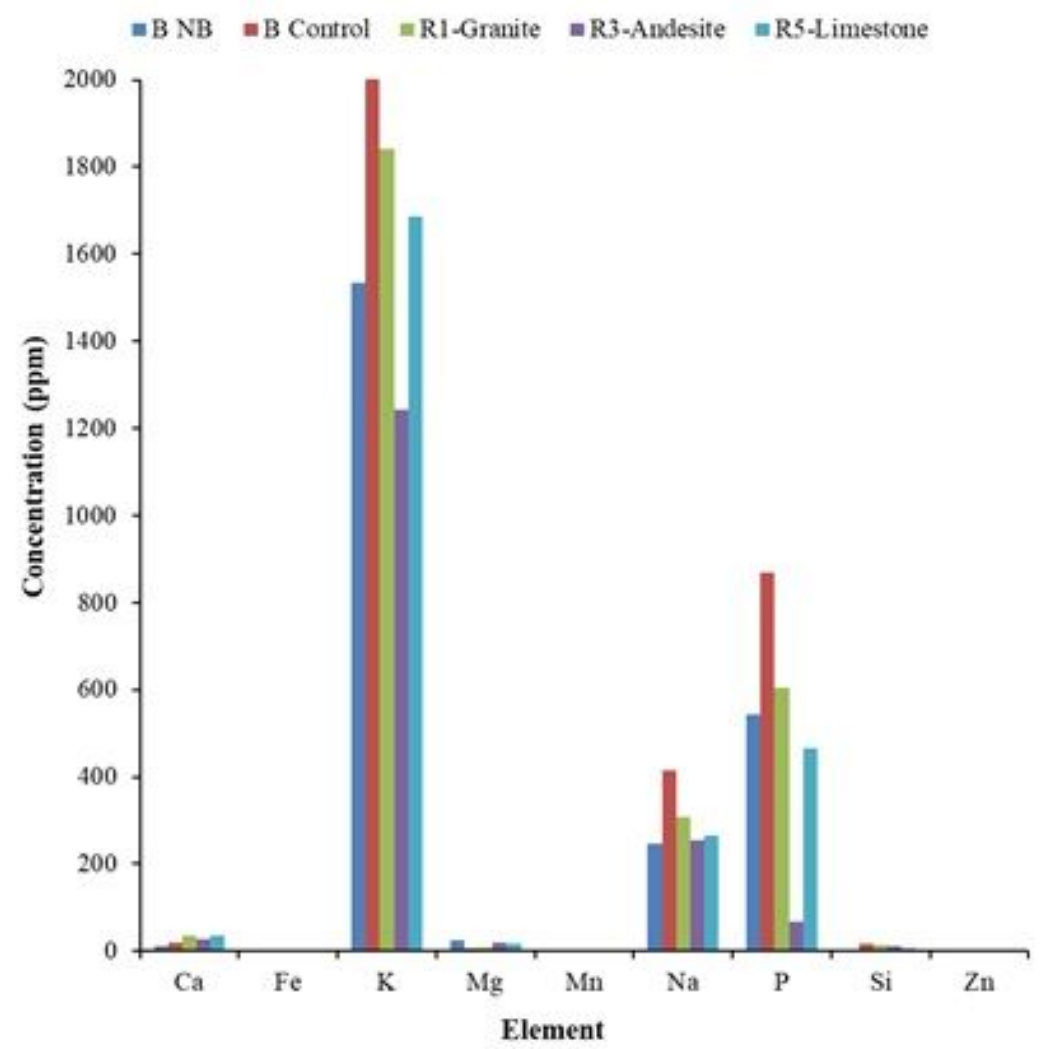

Figure 25

Elemental analysis plot for B. subtilis experiments

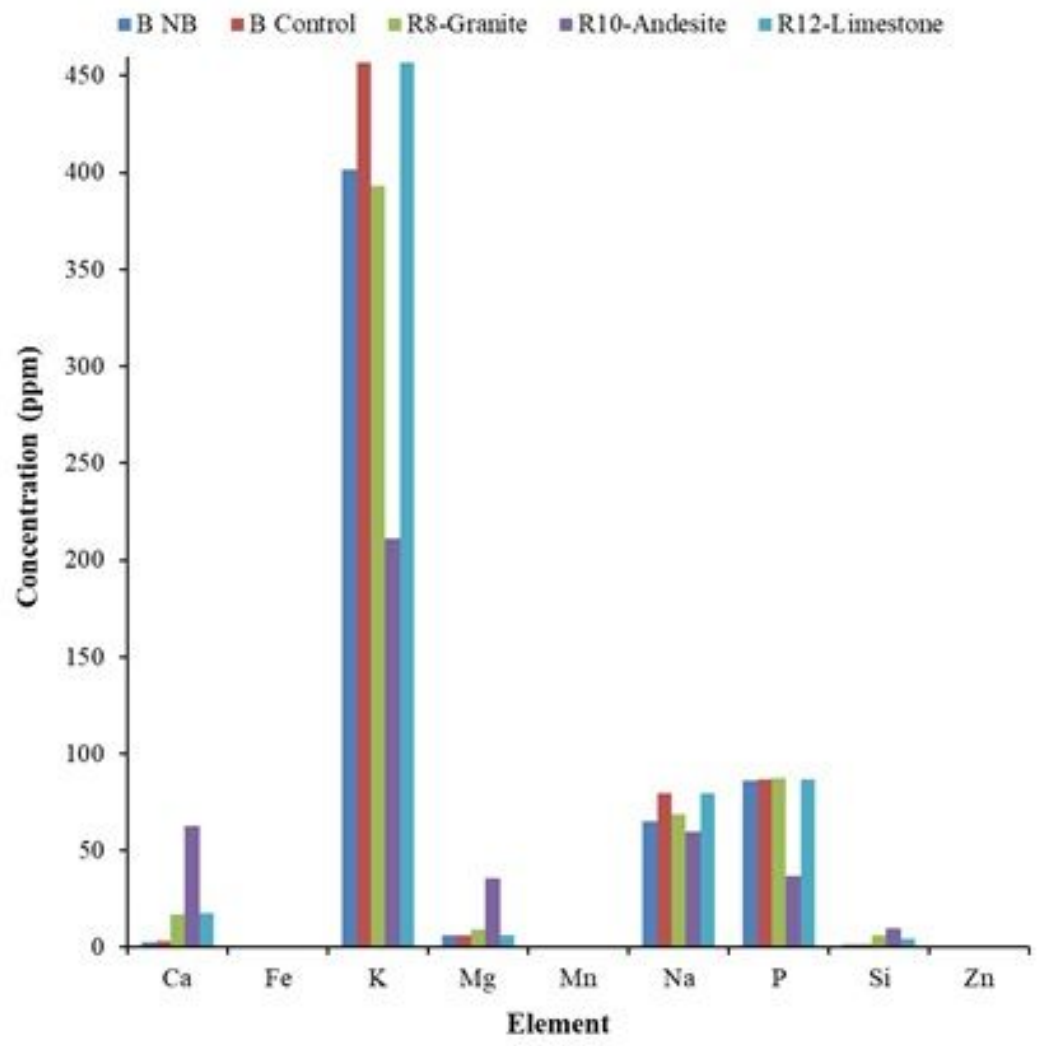

Figure 26 
Elemental analysis plot for B. pumilus experiments 